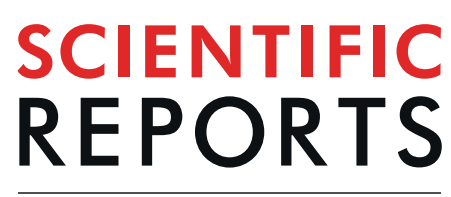

natureresearch

\title{
Voltage-Dependent Protonation of the Calcium Pocket Enable Activation of the Calcium-Activated Chloride Channel Anoctamin-1 (TMEM16A)
}

Guadalupe Segura-Covarrubias ${ }^{1}$, Iván A. Aréchiga-Figueroa ${ }^{3}$, José J. De Jesús-Pérez ${ }^{2}$, Alfredo Sánchez-Solano ${ }^{2}$, Patricia Pérez-Cornejo ${ }^{3} \&$ Jorge Arreola ${ }^{2 *}$

\begin{abstract}
Anoctamin-1 (ANO1 or TMEM16A) is a homo-dimeric $\mathrm{Ca}^{2+}$-activated $\mathrm{Cl}^{-}$channel responsible for essential physiological processes. Each monomer harbours a pore and $\mathrm{a} \mathrm{Ca}^{2+}$-binding pocket; the voltage-dependent binding of two intracellular $\mathrm{Ca}^{2+}$ ions to the pocket gates the pore. However, in the absence of intracellular $\mathrm{Ca}^{2+}$ voltage activates TMEM16A by an unknown mechanism. Here we show voltage-activated anion currents that are outwardly rectifying, time-independent with fast or absent tail currents that are inhibited by tannic and anthracene-9-carboxylic acids. Since intracellular protons compete with $\mathrm{Ca}^{2+}$ for binding sites in the pocket, we hypothesized that voltage-dependent titration of these sites would induce gating. Indeed intracellular acidification enabled activation of TMEM16A by voltage-dependent protonation, which enhanced the open probability of the channel. Mutating Glu/ Asp residues in the $\mathrm{Ca}^{2+}$-binding pocket to glutamine (to resemble a permanent protonated $\mathrm{Glu}$ ) yielded channels that were easier to activate at physiological pH. Notably, the response of these mutants to intracellular acidification was diminished and became voltage-independent. Thus, voltage-dependent protonation of glutamate/aspartate residues (Glu/Asp) located in the $\mathrm{Ca}^{2+}$-binding pocket underlines TMEM16A activation in the absence of intracellular $\mathrm{Ca}^{2+}$.
\end{abstract}

Anoctamin-1 (ANO1 or TMEM16A) and Anoctamin-2 (ANO2 or TMEM16B) are the pore-forming subunits of $\mathrm{Ca}^{2+}$-activated $\mathrm{Cl}^{-}$channels $(\mathrm{CaCCs})^{1-3}$. Several tissues express $\mathrm{CaCC}$ that participate in vital physiological functions ${ }^{4,5}$. Thus, a role for TMEM16A and TMEM16B in smooth muscle contraction, control of blood pressure, control of gastrointestinal movements, regulation of cardiac and neuronal excitability, fluid secretion in exocrine glands, secretion of melatonin, mucin and insulin, sperm capacitation and motility, inhibition of polyspermy, and sensory transduction was established using tissue-specific knockout mice ${ }^{6-16}$. In addition, TMEM16A modulates the partitioning of membrane phosphoinositides and endocytic transport by controlling the $\left[\mathrm{Cl}^{-}\right]_{\mathrm{i}}{ }^{17}$. Overexpression of TMEM16A is associated with hypertension, increased cell proliferation and cancer progression $^{18-21}$.

Activation of CaCCs is triggered by voltage-dependent binding of two $\mathrm{Ca}^{2+}$ ions to the channel when the intracellular $\mathrm{Ca}^{2+}$ concentration $\left(\left[\mathrm{Ca}^{2+}\right]_{\mathrm{i}}\right)$ increases ${ }^{22-26}$. Structural and mutagenesis analysis show that $\mathrm{Ca}^{2+}$ ions bind to an acidic $\mathrm{Ca}^{2+}$ pocket formed by four Glu, one Asp and one $\mathrm{Asn}^{25-27}$. The pocket is located near the cytosolic side facing the permeation pathway. However, other divalent cations and maybe trivalent cations too can support TMEM16A activation. Based on the cation concentrations to obtain the half-maximum response, the cation selectivity of TMEM16A gating machinery is $\mathrm{Ca}^{2+}{ }_{\|} \mathrm{Sr}^{2+}{ }_{\gg} \mathrm{Ba}^{2+}{ } \mathrm{Cd}^{2+}, 23,27-29 . \mathrm{Gd}^{3+}$ may also activate TMEM16A since its application removed the inward rectification of the Gly644Pro TMEM16A mutant channel ${ }^{30}$.

${ }^{1}$ Division de Biología Molecular del Instituto Potosino de Investigación Científica y Tecnológica. Camino a la Presa de San José 2055, San Luis Potosí, SLP, 78216, México. ²Physics Institute, Universidad Autónoma de San Luis Potosí, Ave. Dr. Manuel Nava \#6, San Luis Potosí, SLP, 78290, México. ${ }^{3}$ Department of Physiology and Biophysics, Universidad Autónoma de San Luis Potosí School of Medicine, Ave. V. Carranza 2405, San Luis Potosí, SLP, 78290, México. *email: arreola@dec1.ifisica.vaslp.mx 
$\mathrm{Mg}^{2+}$, the most abundant divalent cation in the cytoplasm of our cells ${ }^{31}$ is unable to activate TMEM16A, however, $\mathrm{Mg}^{2+}$ competes with $\mathrm{Ca}^{2+}$ and decreases the apparent $\mathrm{Ca}^{2+}$ sensitivity of TMEM16A ${ }^{29}$. Despite its low cation selectivity, the $\mathrm{Ca}^{2+}$-binding pocket of TMEM16A does not interact with monovalent cations. Due to its acidic chemical nature, the $\mathrm{Ca}^{2+}$-binding pocket is prompt to protonation. In fact, intracellular $\mathrm{H}^{+}$compete with $\mathrm{Ca}^{2+}$ for these acidic residues. By doing so, $\mathrm{H}^{+}$decreases the $\mathrm{Ca}^{2+}$ affinity of TMEM16A causing a reduction in channel activity ${ }^{32,33}$. Thus, intracellular $\mathrm{H}^{+}$interact with the pocket, but can this interaction prompt TMEM16A activation? In this work, we demonstrate that voltage activation of TMEM16A in the absence of intracellular $\mathrm{Ca}^{2+}$ is due to voltage-dependent titration of the $\mathrm{Ca}^{2+}$-binding pocket. In the absence of $\mathrm{Ca}^{2+}$ voltage induced strong outwardly rectifying anion currents sensitive to TMEM16A inhibitors. These currents activate and deactivate very fast $(<1 \mathrm{~ms})$ and displayed little time dependence. Furthermore, we show that $\mathrm{Ca}^{2+}$-independent activation of TMEM16A under acidic conditions resulted from voltage-dependent protonation of Glu/Asp residues.

\section{Results}

Voltage activation of TMEM16A in the absence of intracellular calcium. To study voltage-dependent gating of TMEM16A in the absence of intracellular $\mathrm{Ca}^{2+}$, we recorded whole cell currents from HEK-293 cells expressing TMEM16A dialyzed with a solution containing $25.24 \mathrm{mM}$ EGTA without $\mathrm{Ca}^{2+}$. Under this condition, a current induced by voltage $(\mathrm{Vm})$ is likely to result from gating of TMEM16A and we will refer to it as Vm-activated TMEM16A current or $\mathrm{I}_{\mathrm{Cl}, \mathrm{Vm}}$. Figure $1 \mathrm{~A}$ shows a set of $\mathrm{I}_{\mathrm{Cl}, \mathrm{Vm}}$ recorded from a cell stimulated with the $\mathrm{Vm}$ protocol shown in Fig. 1G. At positive $\mathrm{Vm}, \mathrm{I}_{\mathrm{Cl}, \mathrm{Vm}}$ activates and deactivates very fast. The time constant of activation was $0.59 \pm 0.11 \mathrm{~ms}$ at $+160 \mathrm{mV}(\mathrm{n}=5)$; no tail currents were recorded upon repolarizing at -100 $\mathrm{mV}$. The magnitude of $\mathrm{I}_{\mathrm{Cl}, \mathrm{Vm}}$ was constant during the entire stimulus duration. This behaviour contrasted with the classical time-dependent $\mathrm{I}_{\mathrm{Cl}}$ generated upon depolarization and the corresponding large tail currents induced by repolarizing to $-100 \mathrm{mV}$ in the presence of $0.2 \mu \mathrm{M} \mathrm{Ca}^{2+}$ (Fig. 1B). The corresponding $\mathrm{I}_{\mathrm{Cl}, \mathrm{Vm}}-\mathrm{Vm}$ curves show that TMEM16A displays strong outward rectification in the absence of intracellular $\mathrm{Ca}^{2+}$ (blue). The magnitude of $\mathrm{I}_{\mathrm{Cl}, \mathrm{Vm}}$ was small; at $+160 \mathrm{mV}$, it was about 10 times smaller than that observed in the presence of $0.2 \mu \mathrm{M} \mathrm{Ca}^{2+}$ (blue vs black). In contrast, TMEM16B, a paralog of TMEM16A, was activated in cells dialysed with $2.5 \mu \mathrm{M} \mathrm{Ca}^{2+}$ but not in cells dialysed with $25.24 \mathrm{mM}$ EGTA and $0 \mathrm{Ca}^{2+}$ (Fig. 1C). To corroborate that TMEM16A is anion-selective in $0 \mathrm{Ca}^{2+}$ we determined the anion-dependence of $\mathrm{I}_{\mathrm{Cl}, \mathrm{Vm}}$. Figure $1 \mathrm{D}$ displays $\mathrm{I}_{\mathrm{Cl}, \mathrm{Vm}}-\mathrm{Vm}$ relationships (left) obtained from cells dialysed with $0 \mathrm{Ca}^{2+}$ and exposed to the indicated anions on the extracellular side. Because $\mathrm{I}_{\mathrm{Cl}, \mathrm{Vm}}$ displays strong outward rectification, we could not reliably measure reversal potentials to determine the anion selectivity sequence from permeability ratios. However, by taking the ratio of $\mathrm{I}_{\mathrm{X}, \mathrm{Vm}}$ (the current carried by anion $\mathrm{X})$ relative to $\mathrm{I}_{\mathrm{Cl}, \mathrm{Vm}}$ at $+160 \mathrm{mV}$ we obtained the following anion selectivity sequence: $\mathrm{SCN}^{-}(7.7 \pm 0.70$; $\mathrm{n}=6), \mathrm{I}^{-}(3.9 \pm 0.16 ; \mathrm{n}=5), \mathrm{NO}_{3}^{-}(2.6 \pm 0.29 ; \mathrm{n}=5), \mathrm{Br}^{-}(1.38 \pm 0.22 ; \mathrm{n}=5)$, and $\mathrm{Cl}^{-}(1.0 ; \mathrm{n}=10)$. This sequence was the same as that obtained in the presence of $0.2 \mu \mathrm{M} \mathrm{Ca}^{2+}$ (Supplementary Fig. S1). Next, we examined the sensitivity of $\mathrm{I}_{\mathrm{Cl}, \mathrm{Vm}}$ to tannic and anthracene-9-carboxylic (A-9-C) acids, blockers of TMEM16A. Figure 1E shows concentration-response curves at $+160 \mathrm{mV}$ obtained from cells dialysed with $0 \mathrm{Ca}^{2+}$ solutions and exposed to increasing concentrations of tannic and A-9-C acids. $\mathrm{I}_{\mathrm{Cl}, \mathrm{Vm}}$ was inhibited with $\mathrm{IC}_{50}$ values of $18.2 \pm 1.7 \mu \mathrm{M}$ and $0.98 \pm 0.22 \mathrm{mM}$, respectively. The $\mathrm{IC}_{50}$ values determined for both inhibitors are like those reported in the presence of $\mathrm{Ca}^{2+34,35}$. Finally, we recorded from mock-transfected HEK-293 cells dialyzed with 0 or $0.2 \mu \mathrm{M} \mathrm{Ca}{ }^{2+}$ but we did not observe endogenous currents activated by Vm (Fig. 1F). Taken together, these results show that Vm activates TMEM16A in the absence of intracellular $\mathrm{Ca}^{2+}$.

Voltage-dependent protonation of TMEM16A enables activation. Under physiological $\left[\mathrm{Ca}^{2+}\right]_{\mathrm{i}}$ and $\left[\mathrm{H}^{+}\right]_{\mathrm{i}}$, TMEM16A is gated by Vm-dependent binding of intracellular $\mathrm{Ca}^{2+}$ to the $\mathrm{Ca}^{2+}$-binding pocket ${ }^{22-25}$. However, intracellular acidification in the presence of $\mathrm{Ca}^{2+}$ inhibited $\mathrm{Ca}^{2+}$-activated $\mathrm{Cl}^{-}$currents in salivary acinar cells and HEK-293 cells expressing TMEM16A by competing for high-affinity binding sites in the $\mathrm{Ca}^{2+}$-binding pocket ${ }^{32,33}$. Based on this observation we hypothesized that positive Vm could drive intracellular $\mathrm{H}^{+}$into the $\mathrm{Ca}^{2+}$-binding pocket to protonate $\mathrm{Glu} /$ Asp residues, open the channel and thus generate $\mathrm{I}_{\mathrm{Cl}, \mathrm{Vm}}$. To test this idea, we recorded $\mathrm{I}_{\mathrm{Cl}, \mathrm{Vm}}$ from TMEM16A-expressing HEK-293 cells dialyzed with an internal solution containing $25.24 \mathrm{mM}$ EGTA/0 $\mathrm{Ca}^{2+}$. The $\mathrm{pH}$ of this solution was adjusted to 8.0, 7.3, 6.0, 5.0, and 4.0 thus changing the $\left[\mathrm{H}^{+}\right]_{\mathrm{i}}$ by four-orders of magnitude. To ensure that $\mathrm{pH}_{\mathrm{i}}$ remained constant during our recordings, we increased the buffer capacity of the solutions by adjusting the $\mathrm{pH}$ with $50 \mathrm{mM}$ of bicine (8.0), HEPES (7.3), MES (6.0, 5.0, and 4.0), citric acid (5.0), or tartaric acid (4.0). No difference in channel activation was observed between data obtained with different buffers at the same $\mathrm{pH}$. Figure $2 \mathrm{~A}$ shows $\mathrm{I}_{\mathrm{Cl}, \mathrm{Vm}}$ recorded at $-100,-40,+20$, $+60,+120$ and $+160 \mathrm{mV}$ using the protocol shown in Fig. $1 \mathrm{G}$. Each row shows $\mathrm{I}_{\mathrm{Cl}, \mathrm{Vm}}$ recorded at the indicated $\mathrm{pH}$ (left column), traces are representative of 5 independent experiments. $\mathrm{As}_{\mathrm{pH}}$ decreased from 8.0 (top) to 4.0 (bottom), the magnitude of $\mathrm{I}_{\mathrm{Cl}, \mathrm{Vm}}$ increased. Under acidic conditions $\mathrm{I}_{\mathrm{Cl}, \mathrm{Vm}}$ activated and deactivated very rapidly. At $+160 \mathrm{mV}$, the time constant of activation was $0.24 \pm 0.02 \mathrm{~ms}$ at $\mathrm{pH}_{\mathrm{i}}=4(\mathrm{n}=5)$. Tail currents were nearly absent but at $\mathrm{pH}_{\mathrm{i}} 4.0$ a small and fast inward current became evident (inset shows a magnification of the tail current). The corresponding $\mathrm{I}_{\mathrm{Cl}, \mathrm{Vm}}-\mathrm{Vm}$ relationships are shown on the right column of Fig. $2 \mathrm{~A}$. At $-100 \mathrm{mV}$ a reduction of $\mathrm{pH}_{\mathrm{i}}$ from 6 to 4.0 produced a 5 -fold increase in $\mathrm{I}_{\mathrm{Cl}, \mathrm{Vm}}(-1.5 \pm 0.4$ to $-7.5 \pm 2.7 \mathrm{pA} / \mathrm{pF}, \mathrm{n}=5$. Lastly, no currents were recorded from HEK-293 cells transfected with the empty vector or dialyzed with $\mathrm{pH}_{\mathrm{i}} 4.0$ containing EGTA or BAPTA (Supplementary Fig. S2). Hence, the potentiation of $\mathrm{I}_{\mathrm{Cl}, \mathrm{Vm}}$ under acidic conditions resulted from activation of TMEM16A. Unfortunately, the effect of intracellular $\mathrm{H}^{+}$on the $\mathrm{Vm}$-dependent activation of $\mathrm{I}_{\mathrm{Cl}, \mathrm{Vm}}$ cannot be deduced from the analysis of macroscopic conductance $\left(\mathrm{G}=\mathrm{I}_{\mathrm{Cl}, \mathrm{Vm}} / \mathrm{Vm}-\mathrm{Vr}\right)$ vs Vm at different $\left[\mathrm{H}^{+}\right]_{\mathrm{i}}$ for two reasons. First, the reversal potentials $(\mathrm{Vr})$ measurements at $\mathrm{pH}_{\mathrm{i}} \geq 6.0$ were unreliable due to $\mathrm{I}_{\mathrm{Cl}, \mathrm{Vm}}$ rectification (at $\mathrm{pH}_{\mathrm{i}} 5$ and 4 , reversal potentials were $-34.4 \pm 2.3$ and $-31.4 \pm 0.8 \mathrm{mV}$, respectively, closer to the expected reversal potential for $\left.\mathrm{Cl}^{-}\right)$. Second, the instantaneous current-voltage relationship after a depolarization to $+160 \mathrm{mV}$ was not linear (Supplementary Fig. S3, blue) indicating that $\mathrm{I}_{\mathrm{Cl}, \mathrm{Vm}}$ does not follow Ohm's law and the tail current 
A

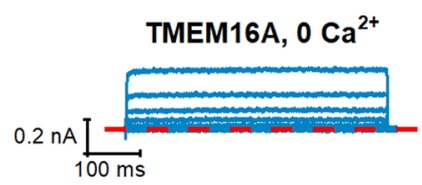

B TMEM16A, $0.2 \mu \mathrm{M} \mathrm{Ca}^{2+}$

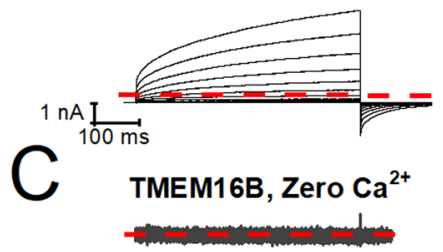

TMEM16B, $2.5 \mu \mathrm{M} \mathrm{Ca}{ }^{2+}$

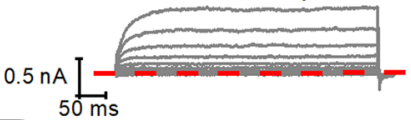

D

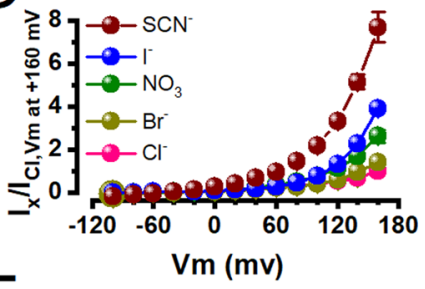

E

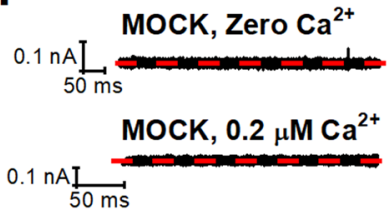

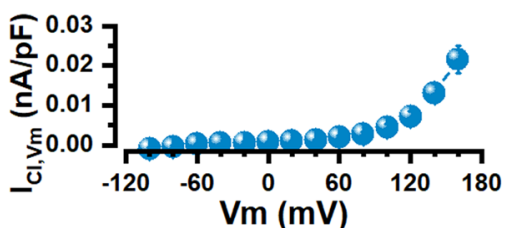
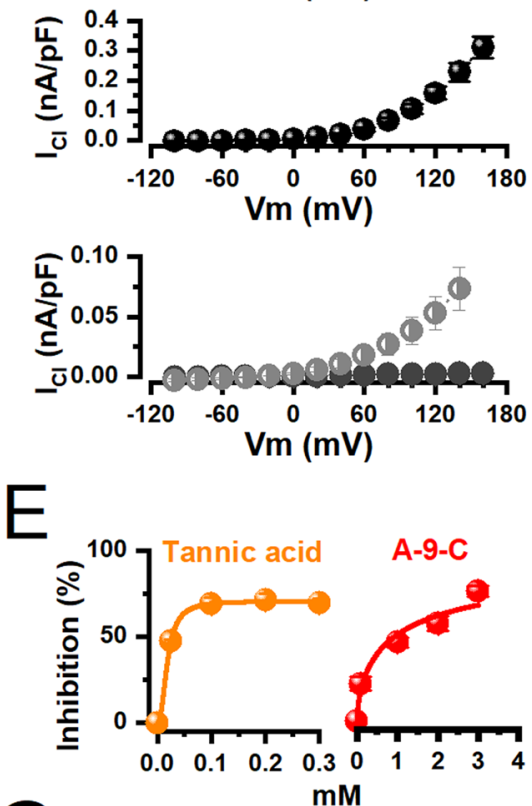

G

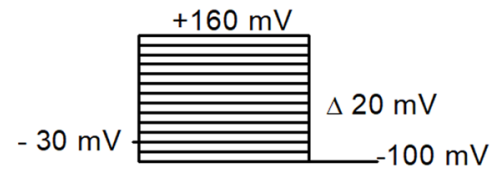

Figure 1. Activation of TMEM16A by voltage in the absence of intracellular calcium. (A) Left: Representative $\mathrm{I}_{\mathrm{Cl}, \mathrm{Vm}}$ recordings obtained from a HEK-293 cell expressing WT TMEM16A and dialysed with $25.24 \mathrm{mM}$ EGTA/0 Ca ${ }^{2+}$. Right: $\mathrm{I}_{\mathrm{Cl}, \mathrm{Vm}}-\mathrm{Vm}$ relationship for WT TMEM16A $\mathrm{I}_{\mathrm{Cl}, \mathrm{Vm}}$ density $(\mathrm{n}=10) .\left[\mathrm{Cl}^{-} \mathrm{Cl}^{-}\right]_{\mathrm{e}} /\left[\mathrm{Cl}^{-}\right]_{\mathrm{i}}=$ $140 / 40 \mathrm{mM}, \mathrm{pH}_{\mathrm{e}} / \mathrm{pH}_{\mathrm{i}}=7.3$. (B) Representative $\mathrm{I}_{\mathrm{Cl}}$ recording obtained from a HEK-293 cell expressing WT TMEM16A and dialysed with $0.2 \mu \mathrm{M} \mathrm{Ca}^{2+}$. Right: $\mathrm{I}_{\mathrm{Cl}}-$ Vm relationship constructed with WT TMEM16A $\mathrm{I}_{\mathrm{Cl}}$ density $(\mathrm{n}=10) .\left[\mathrm{Cl}^{-}\right]_{\mathrm{e}} /\left[\mathrm{Cl}^{-}\right]_{\mathrm{i}}=140 / 40 \mathrm{mM}, \mathrm{pH}_{\mathrm{e}} / \mathrm{pH}_{\mathrm{i}}=7.3$. (C) Representative $\mathrm{I}_{\mathrm{Cl}}$ recordings obtained from two different HEK-293 cells expressing TMEM16B that were dialysed with $0 \mathrm{Ca}^{2+}+25.24 \mathrm{mM}$ EGTA (upper left) or $2.5 \mu \mathrm{M} \mathrm{Ca}^{2+}$ (lower, left). Right: $\mathrm{I}_{\mathrm{Cl}}-\mathrm{Vm}$ relationships constructed with the TMEM16B current density in the absence (black) and in the presence (grey) of $2.5 \mu \mathrm{M} \mathrm{Ca}^{2+} .\left[\mathrm{Cl}^{-}\right]_{\mathrm{e}} /\left[\mathrm{Cl}^{-}\right]_{\mathrm{i}}=140 / 40 \mathrm{mM}, \mathrm{pH}_{\mathrm{e}} / \mathrm{pH}_{\mathrm{i}}=7.3$ $(\mathrm{n}=5)$. (D)Anion selectivity of WT TMEM16A I $\mathrm{Cl}_{\mathrm{Vm}}$ when $\left[\mathrm{Ca}^{2+}\right]_{\mathrm{i}}=0$. The extracellular $\mathrm{Cl}^{-}(140 \mathrm{mM})$ was replaced by the indicated anions. Paired $\mathrm{I}_{\mathrm{Cl}, \mathrm{Vm}}-\mathrm{Vm}$ relationships in the presence of $\mathrm{Cl}^{-}$(control) and then in the presence of a chosen anion (test) were obtained from the same cell. Both relationships were normalized using $\mathrm{I}_{\mathrm{Cl}, \mathrm{Vm}}$ recorded in the presence of $\mathrm{Cl}^{-}$at $+160 \mathrm{mV}$ and averaged. $(\mathrm{n}=5-8)$. (E) Concentrationresponse curves to tannic and anthracene-9-carboxylic acids at $+160 \mathrm{mV}$. Cells were dialyzed with $25.24 \mathrm{mM}$ EGTA/0 $/ \mathrm{Ca}^{2+}$ and bathed in $140 \mathrm{mM} \mathrm{SCN}^{-}$media to increase $\mathrm{I}_{\mathrm{Cl}, \mathrm{Vm}}$ size. Continuous lines are fits to Hill's equation with $\mathrm{IC}_{50} / \mathrm{N} / \mathrm{R}^{2}$ values of $18.2 \pm 1.7 \mu \mathrm{M} / 2.2 / 0.999(\mathrm{n}=3-4)$ and $0.98 \pm 0.22 \mathrm{mM} / 0.65 / 0.967(\mathrm{n}=4)$, respectively. (F) Representative recordings obtained from HEK-293 cells transfected with the empty pIRESII-EGFP vector in the absence (upper left) and in the presence of $0.2 \mu \mathrm{M} \mathrm{Ca}^{2+}$ (lower left). $\left[\mathrm{Cl}^{-}\right]_{\mathrm{e}} /\left[\mathrm{Cl}^{-}\right]_{\mathrm{i}}=$ $140 / 40 \mathrm{mM}, \mathrm{pH}_{\mathrm{e}} / \mathrm{pH}_{\mathrm{i}}=7.3,(\mathrm{n}=5)$. (G) The voltage protocol used to activate TMEM16A consisted of a holding potential of $-30 \mathrm{mV}, 250$ or $500 \mathrm{~ms}$ steps between -100 to $+160 \mathrm{mV}$ in $20 \mathrm{mV}$ increments, and unless otherwise indicated, a repolarization $\mathrm{Vm}$ of $-100 \mathrm{mV}$.

magnitudes at $-100 \mathrm{mV}$ (orange) were the same for steps between -100 to $+160 \mathrm{mV}$ as if the open probability was Vm-independent.

To advance the hypothesis that Vm activation of TMEM16A is due to protonation we must show that the equilibrium constant of protonation $(K)$ is $\mathrm{Vm}$-dependent. Figure $2 \mathrm{~B}$ show $\mathrm{I}_{\mathrm{Cl}, \mathrm{Vm}}$ titration curves at different $\mathrm{Vm}$. As the $\left[\mathrm{H}^{+}\right]_{\mathrm{i}}$ increase the magnitude of $\mathrm{I}_{\mathrm{Cl}, \mathrm{Vm}}$ is increased. Unfortunately, only at $+160 \mathrm{mV}$ and $\mathrm{pH}_{\mathrm{i}} 4.0$, we obtained a hint of saturation. Experiments at $\mathrm{pH}_{\mathrm{i}} 3.0$ were not possible because the cells died quickly. Thus, to determine the 

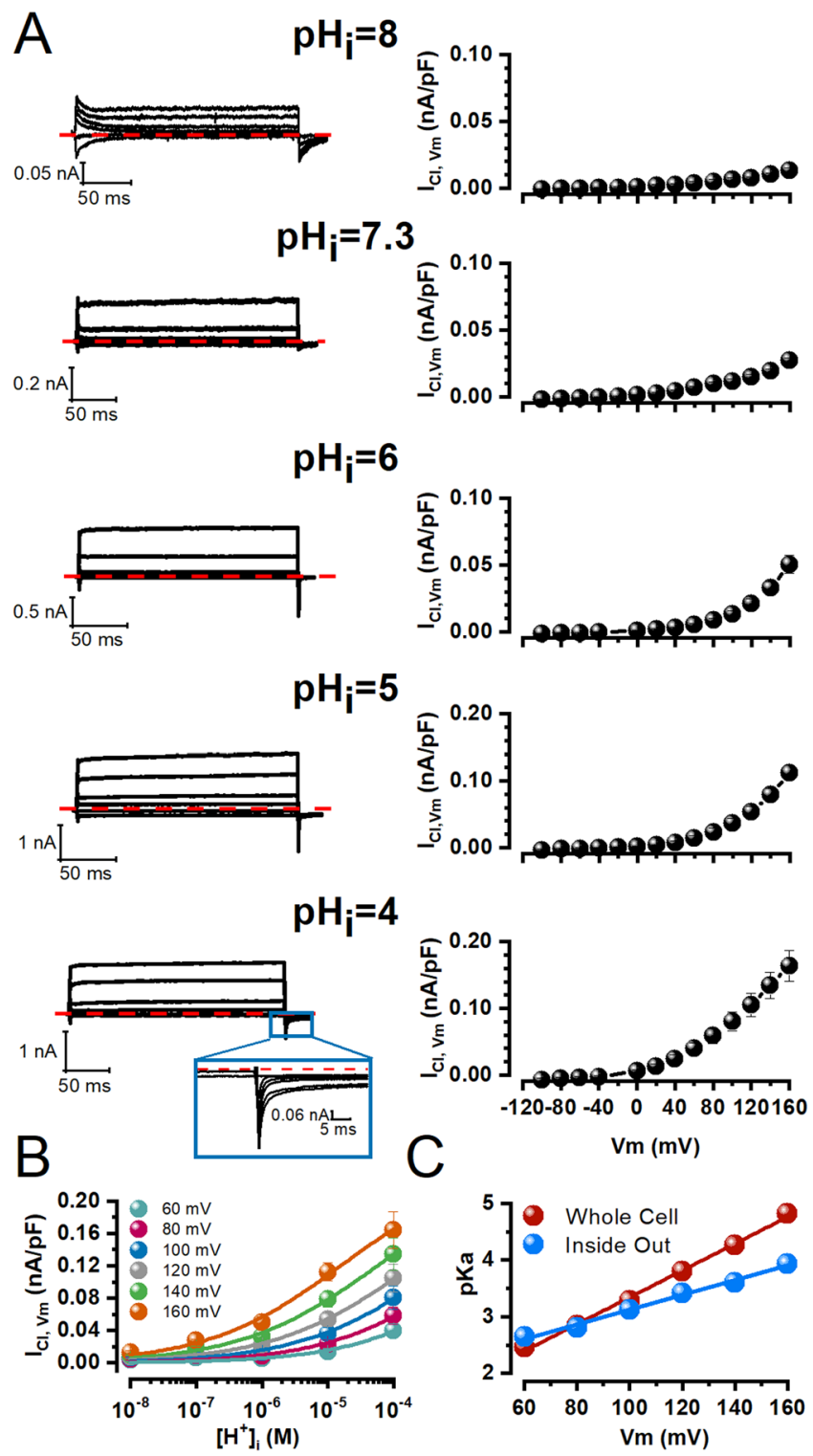

Figure 2. Voltage-dependent protonation facilitates activation of TMEM16A in the absence of intracellular calcium. (A) Representative $\mathrm{I}_{\mathrm{Cl}, \mathrm{Vm}}$ recordings (left) and corresponding $\mathrm{I}_{\mathrm{Cl}, \mathrm{Vm}}$ - Vm relations (right) sampled from different cells dialyzed with an internal solution whose $\mathrm{pH}$ was set to (from top to bottom): $8.0(\mathrm{n}=4), 7.3$ $(n=8), 6.0(n=6), 5.0(n=5)$, and $4.0(n=5)$. Current traces were recorded at $-100,-40,+20,+60,+120$ and $+160 \mathrm{mV}$. An amplification of the tail currents at $\mathrm{pH}_{\mathrm{i}} 4.0$ is shown. $\left[\mathrm{Cl}^{-}\right]_{\mathrm{e}} /\left[\mathrm{Cl}^{-}\right]_{\mathrm{i}}$ were $140 / 40 \mathrm{mM}$ and $\mathrm{pH}_{\mathrm{e}}=$ 7.3 for all cases. (B) Titration curves at the indicated Vm. Continuous lines are fits with the Hill equation (Eq. 1) using a single maximum current density value of $0.23853 \mathrm{nA} / \mathrm{pF}$ determined by fitting the curve at $+160 \mathrm{mV}$. The equilibrium constant of titration $K$ and the Hill coefficient $\mathrm{N}$ were determined from the fits. The $K / \mathrm{N} /$ $R^{2}$ values were $0.0035 \pm 0.002 \mathrm{M} / 0.44 \pm 0.07 / 0.951$ at $60 \mathrm{mV}, 0.0014 \pm 0.00075 \mathrm{M} / 0.43 \pm 0.06 / 0.96$ at $+80 \mathrm{mV}$, $0.00052 \pm 0.00016 \mathrm{M} / 0.42 \pm 0.04 / 0.981$ at $+100 \mathrm{mV}, 0.000159 \pm 0.000029 \mathrm{M} / 0.42 \pm 0.03 / 0.990$ at $+120 \mathrm{mV}$, $0.000055 \pm 0.00000071 \mathrm{M} / 0.42 \pm 0.02 / 0.994$ at +140 , and $0.0000152 \pm 0.0000016 \mathrm{M} / 0.43 \pm 0.076 / 0.990$ at $+160 \mathrm{mV}$. (C) Vm dependence of the equilibrium constant of protonation $K$ determined from data shown in B. Continuous line is the fit with Eq. 2 with a $\delta$ value of $1.39 \pm 0.04$ and $\mathrm{pK}_{0}$ of $0.97 \pm 0.07$. For comparison, we plotted in blue average $p K a$ values calculated from two titration curves obtained from two inside out patches. The continuous blue line is the fit with Eq. 2 with a $\delta$ value of $0.77 \pm 0.03$ and $\mathrm{pK}_{0}$ of $1.82 \pm 0.06$.

equilibrium constant of protonation $(K)$ at each $\mathrm{Vm}$, we first fitted the data collected at $+160 \mathrm{mV}$ to a Hill equation (Eq. 1) to obtain an $\mathrm{I}_{\mathrm{Cl}, \mathrm{Vm}}$ maximum. Then we used this value in the Hill equation to fit all the curves. This way, our fitting procedure had only two free parameters, $K$ and Hill coefficient (N). Continuous lines in Fig. 2B and their corresponding $\mathrm{R}^{2}$ values show that this fitting procedure is a good quantitative description of the experimental data at all $\mathrm{Vm}$. Figure $2 \mathrm{C}$ displays the resulting $p K a\left(=-\log _{10} K\right)$ values as a function of $\mathrm{Vm}$. At positive $\mathrm{Vm}$, the $p K a$ value increased indicating that less $\mathrm{H}^{+}$are required to generate $50 \%$ of $\mathrm{I}_{\mathrm{Cl}, \mathrm{Vm}}$. This Vm dependence of $p K a$ resembles the $\mathrm{Vm}$ dependence of $\mathrm{EC}_{50}$ for intracellular $\mathrm{Ca}^{2+22}$. The relation $p K a-\mathrm{Vm}$ was fit with Eq. 2 to 


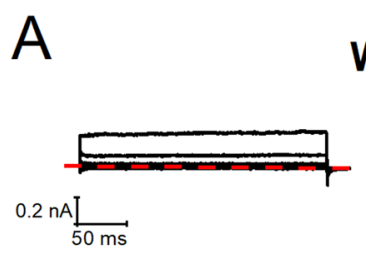

\section{WT}

\section{$2 M$}
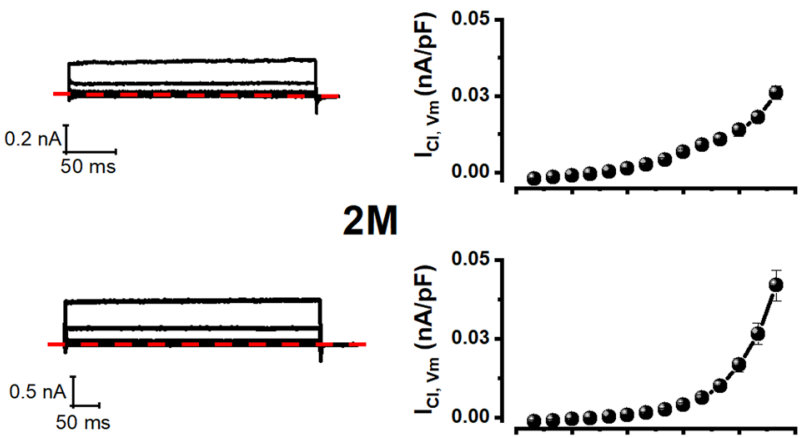

$3 M$
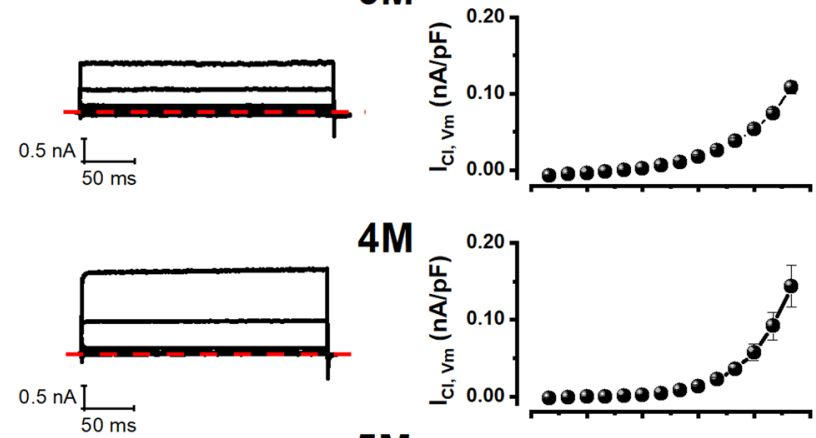

4M
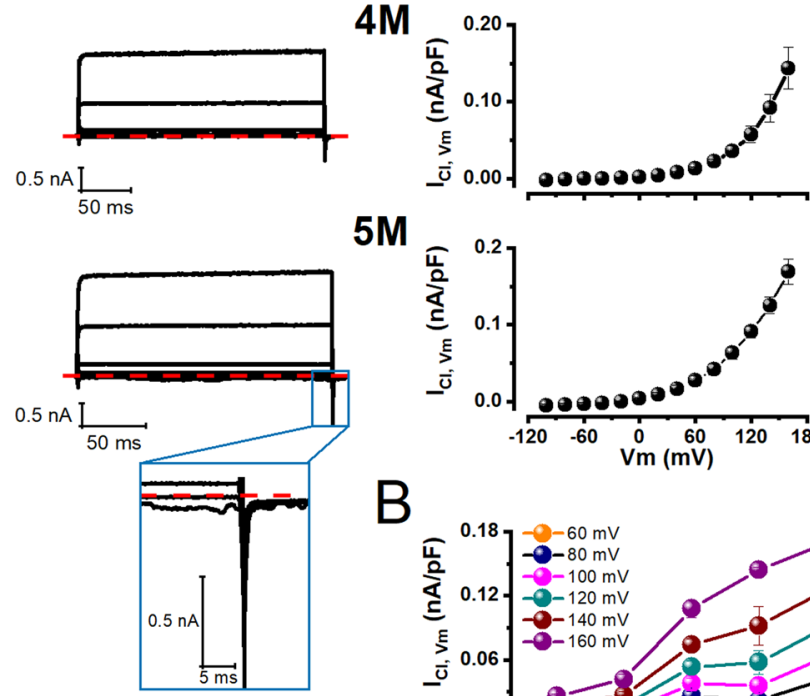

$5 \mathrm{M}$

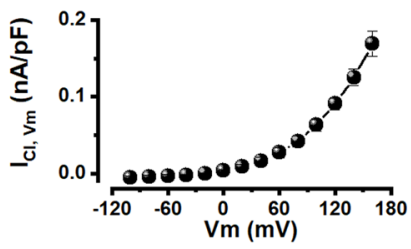

$\mathrm{B}$

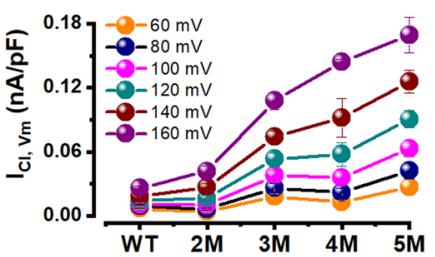

Figure 3. Mutating acidic residues (Glu to Gln) from the $\mathrm{Ca}^{2+}$-binding pocket enhanced the voltage activation of TMEM16A at physiological intracellular $\mathrm{pH}$. (A) Representative $\mathrm{I}_{\mathrm{Cl}, \mathrm{Vm}}$ recordings (left) sampled from different cells expressing from top to bottom WT $(n=8), 2 M(n=5), 3 M(n=6), 4 M(n=6)$, and $5 M(n=6)$ TMEM16A channels and their corresponding $\mathrm{I}_{\mathrm{Cl}, \mathrm{Vm}}-\mathrm{Vm}$ relations (right). Note the absence of tail currents in these recordings (Inset: tail currents from $5 \mathrm{M}$ ). In all recordings: $\left[\mathrm{Cl}^{-}\right]_{\mathrm{e}} /\left[\mathrm{Cl}^{-}\right]_{\mathrm{i}}=140 / 40 \mathrm{mM}, \mathrm{pH}_{\mathrm{e}} / \mathrm{pH}_{\mathrm{i}}=7.3 / 7.3$ and $\left[\mathrm{Ca}^{2+}\right]_{\mathrm{i}}=0$. (B) Current density vs the number of acidic residues mutated into Gln at different Vm.

calculate $K_{0}$ (equilibrium constant of protonation at $0 \mathrm{mV}$ and $\delta$, the fraction of electrical field sensed by $\mathrm{H}^{+}$going from the intracellular side to the extracellular side). A $p K_{0}$ value of $0.97 \pm 0.07$ and a $\delta$ value of $1.39 \pm 0.04$ were estimated this way. We conducted similar experiments with inside-out patches; unfortunately, most patches were unstable at acidic conditions. Figure $2 \mathrm{C}$ (blue symbols) shows averaged data obtained from two super-patches (Supplementary Fig. S4) that withstood exposure to $\mathrm{pH}_{\mathrm{i}} 8.0,6.0,5.0$, and 4.0. The $p K a$ obtained from inside-out patches has a similar Vm-dependence as the $p K a$ obtained from whole cell recordings. In this case, the average $p K_{0}$ and $\delta$ values were 1.77 and 0.79 , respectively. Thus, taken together our results support the hypothesis that $\mathrm{Vm}$ gates TMEM16A due to intracellular protonation.

Voltage-dependent protonation of glutamate and aspartate residues located in the $\mathrm{Ca}^{2+}$-binding pocket increase the open probability of TMEM16A. To identify Glu and Asp residues within the $\mathrm{Ca}^{2+}$-binding pocket that are targets of intracellular $\mathrm{H}^{+}$we mutated in an incremental fashion $4 \mathrm{Glu}$ and 1 Asp residues. These residues were mutated into Gln to resemble a permanent protonated Glu side chain. We reasoned that if $\mathrm{H}^{+}$neutralizes the $\mathrm{COO}^{-}$group of Glu and Asp residues to activate wild type TMEM16A (WT) then Vm would activate Gln mutants at $\mathrm{pH}_{\mathrm{i}} 7.3$ without the need for acidification. Figure $3 \mathrm{~A}$ shows $\mathrm{I}_{\mathrm{Cl}, \mathrm{Vm}}$ 
A

WT

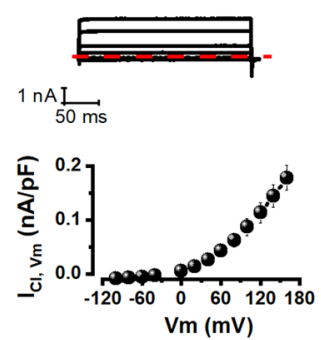

$2 \mathrm{M}$
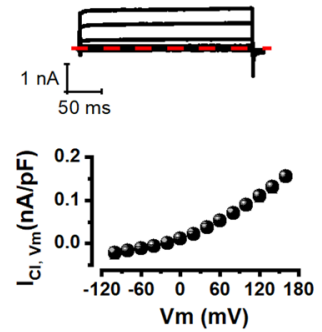

$3 \mathrm{M}$
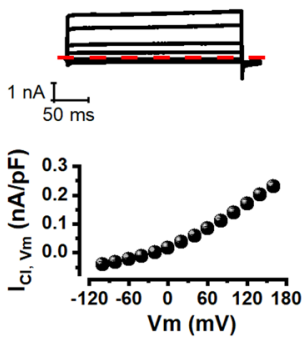

$4 \mathrm{M}$
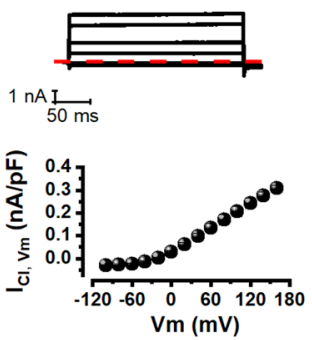

$5 \mathrm{M}$
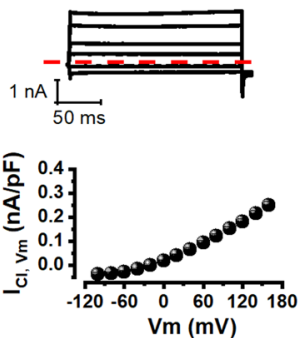
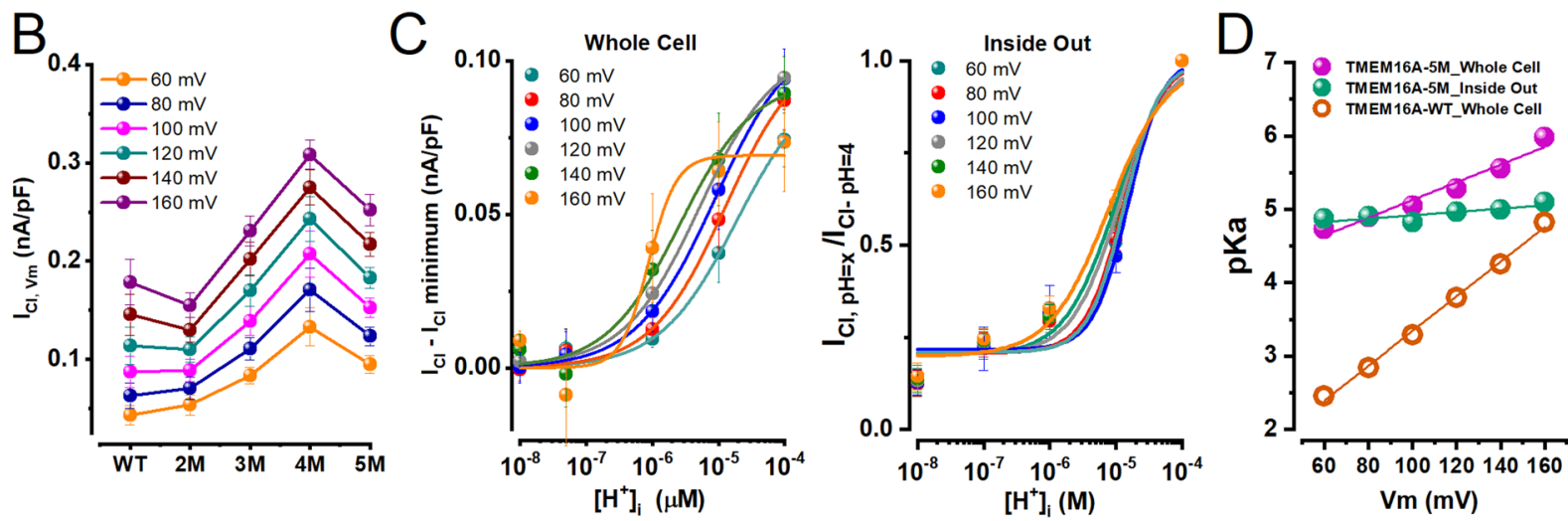

Figure 4. $\mathrm{Ca}^{2+}$-binding pocket mutants are less sensitive to intracellular acidification. (A) Representative $\mathrm{I}_{\mathrm{Cl}, \mathrm{Vm}}$ recordings (upper panels) and their corresponding $\mathrm{I}_{\mathrm{Cl}, \mathrm{Vm}}-\mathrm{Vm}$ relations (lower panels). From left to right: WT $(n=5), 2 M(n=5), 3 M(n=5), 4 M(n=6)$, and $5 M(n=6)$ TMEM16A channels. $I_{C l, V m}$ were sampled from different cells dialyzed with an internal solution whose $\mathrm{pH}$ was set to 4.0 and $\left[\mathrm{Ca}^{2+}\right]_{\mathrm{i}}=0$. Note the presence of tiny tail currents. $\left[\mathrm{Cl}^{-}\right]_{\mathrm{e}} /\left[\mathrm{Cl}^{-}\right]_{\mathrm{i}}=140 / 40 \mathrm{mM}, \mathrm{pH}_{\mathrm{e}} / \mathrm{pH}_{\mathrm{i}}=7.3 / 4.0$ and $\left[\mathrm{Ca}^{2+}\right]_{\mathrm{i}}=0$ in all cases. (B) Current density vs the number of acidic residues mutated into Gln at different Vm. (C) Titration curves of $5 \mathrm{M}$ TMEM16A channels in the range of +60 to $+160 \mathrm{mV}$. Curves were constructed using whole cell $\mathrm{I}_{\mathrm{Cl}, V \mathrm{~m}}$ (left) or inside-out $\mathrm{I}_{\mathrm{Cl}, \mathrm{Vm}}$ (right) data and then fitting the curves with the Hill equation (Eq. 1, continuous lines) to determine $K$ values at each Vm. (D) The Vm dependence of $p K a$ was dampened in 5M TMEM16A channels. Purple and green spheres show $p K a$ values at different Vm calculated using the whole cell and insideout data, respectively. Continuous lines are fits with Eq. 2 to obtain $p K_{O}$ and the $\delta$, the fraction of electrical distance. The corresponding values for whole cell and inside out data were $3.91 \pm 0.14 / 0.71 \pm 0.72$ and $4.69 \pm 0.08 / 0.13 \pm 0.04$, respectively. For comparison, the Vm dependence of WT $p K a$ is shown in orange.

recordings at $-100,-40,+20,+60,+120$ and $+160 \mathrm{mV}$ from five independent cells expressing (from top to bottom) WT, E702Q/E705Q (2 M), E702Q/E705Q/E734Q (3 M), E702Q/E705Q/E734Q/D738Q (4 M), and E654Q/

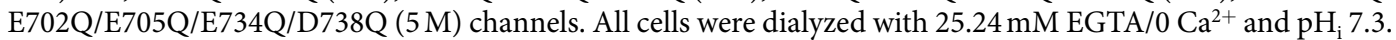
As the number of mutations accumulates, the magnitude of $\mathrm{I}_{\mathrm{Cl}, \mathrm{Vm}}$ increased mirroring the effect of intracellular acidification. $\mathrm{I}_{\mathrm{Cl}, \mathrm{Vm}}$ onset was fast, had no time dependence and no tail currents at $-100 \mathrm{mV}$. Very fast tail currents were observed only with the quintuple mutant (see magnification in the lower-left panel). The corresponding $\mathrm{I}_{\mathrm{Cl}, \mathrm{Vm}}-\mathrm{Vm}$ relationships (Fig. 3A, right column) displayed outward rectification just like WT channels but the rectification changed without showing a particular pattern. Although the magnitude of $\mathrm{I}_{\mathrm{Cl}, \mathrm{Vm}}$ increased at all Vm, at $+160 \mathrm{mV} \mathrm{I}_{\mathrm{Cl}, V m}$ appeared to saturate as the number of mutations (or $\mathrm{Gln}$ ) in the $\mathrm{Ca}^{2+}$-binding pocket increased (Fig. 3B). At $\mathrm{pH}_{\mathrm{i}} 7.3$, a strong depolarization $(+160 \mathrm{mV})$ induced a 6.5 -fold increase in $\mathrm{I}_{\mathrm{Cl}, \mathrm{Vm}}$ in $5 \mathrm{M}$ channels compared to WT.

The above data show that mutating the acidic residues of the $\mathrm{Ca}^{2+}$-binding pocket into Gln allowed activation of TMEM16A at $\mathrm{pH}_{\mathrm{i}} 7.3$ in the absence of intracellular $\mathrm{Ca}^{2+}$. If these residues are the main source of Vm sensitivity under acidic conditions, then increasing the $\left[\mathrm{H}^{+}\right]_{\mathrm{i}}$ should have little or no additional effect on $\mathrm{I}_{\mathrm{Cl}, \mathrm{Vm}}$, and the Vm dependence of $p K a$ should be abolished. To test these predictions, we recorded $\mathrm{I}_{\mathrm{Cl}, \mathrm{Vm}}$ from cells dialyzed with an intracellular solution with $\mathrm{pH}_{\mathrm{i}}$ 4. Figure $4 \mathrm{~A}$ shows $\mathrm{I}_{\mathrm{Cl}, \mathrm{Vm}}$ recordings for $\mathrm{WT}, 2 \mathrm{M}, 3 \mathrm{M}, 4 \mathrm{M}$, and $5 \mathrm{M}$ channels (left to right). Current kinetics of $\mathrm{I}_{\mathrm{Cl}, \mathrm{Vm}}$ at $\mathrm{pH}_{\mathrm{i}} 4.0$ and 7.3 (compare Fig. $4 \mathrm{~A}$ to Fig. $3 \mathrm{~A}$ ) were quite similar. For example, at $+160 \mathrm{mV}$ the time constant of activation of $5 \mathrm{M}$ channels was $0.46 \pm 0.04 \mathrm{~ms}(\mathrm{n}=5)$ at $\mathrm{pH}_{\mathrm{i}} 7.3$ and $0.77 \pm 0.03 \mathrm{~ms}(\mathrm{n}=5)$ at $\mathrm{pH}_{\mathrm{i}}$ 4.0. The corresponding $\mathrm{I}_{\mathrm{ClVm}}-\mathrm{Vm}$ curves displayed less rectification (Fig. $4 \mathrm{~A}$, bottom panels). Reversal potential values for WT, $2 \mathrm{M}, 3 \mathrm{M}, 4 \mathrm{M}$, and $5 \mathrm{M}$, were $-31.4 \pm 0.8,-31.5 \pm 0.7,-29.2 \pm 0.7$, $-31.0 \pm 2.1$, and $-28.0 \pm 0.9 \mathrm{mV}$, respectively, indicating that at $\mathrm{pH}_{\mathrm{i}} 4.0$ the $\mathrm{I}_{\mathrm{Cl}, \mathrm{Vm}}$ was generated by $\mathrm{Cl}^{-}$fluxes. However, at $\mathrm{pH}_{\mathrm{i}} 4.0$ the magnitude of $\mathrm{I}_{\mathrm{Cl}, \mathrm{Vm}}$ recorded at positive $\mathrm{Vm}$ increased with the number of mutations present (Fig. 4B). A caveat of using $\mathrm{pH}_{\mathrm{i}} 4.0$ to test protonation of Glu and Asp residues is that the probability of protonation is about 0.64 , therefore, comparing WT and mutant channels at $\mathrm{pH}_{\mathrm{i}} 4.0$ may not be straightforward. 

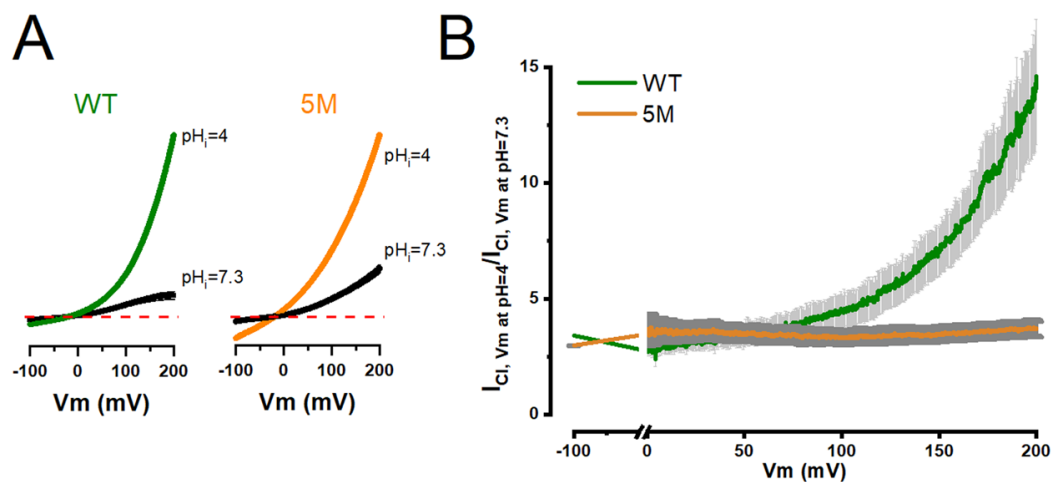

Figure 5. Intracellular acidification enables activation of TMEM16A by increasing the apparent open probability in Vm-dependent and Vm-independent manners. (A) $\mathrm{I}_{\mathrm{Cl}, \mathrm{Vm}}$ - Vm relationships recorded from inside-out patches obtained from HEK-293 cells expressing TMEM16A WT (left panel) or TMEM16A 5M (right panel). The cytosolic side of each patch was sequentially exposed to solutions $\mathrm{pH} 7.3$ and then 4.0. $\mathrm{I}_{\mathrm{Cl}, \mathrm{Vm}}$ - Vm curves were generated applying a ramp protocol that varied Vm between -100 and $200 \mathrm{mV}$ in $624 \mathrm{~ms}$. Paired curves were normalized to the current obtained at $+200 \mathrm{mV}$ and $\mathrm{pH}_{\mathrm{i}}=4.0$. Normalized relations were then averaged. The reversal potentials were: $-36.2 \pm 1.4$ at $\mathrm{pH}_{\mathrm{i}}=7.3$ and $-31.3 \pm 1.4$ at $\mathrm{pH}_{\mathrm{i}}=4.0$ for WT and $-28.3 \pm 1.5$ at $\mathrm{pH}_{\mathrm{i}}=7.3$ and $-23.4 \pm 1.6$ at $\mathrm{pH}_{\mathrm{i}}=4$ for $5 \mathrm{M} .\left[\mathrm{Cl}^{-}\right]_{\mathrm{e}} /\left[\mathrm{Cl}^{-}\right]_{\mathrm{i}}=140 / 40 \mathrm{mM}, \mathrm{pH}_{\mathrm{e}}=7.3$ and $\left[\mathrm{Ca}^{2+}\right]_{\mathrm{i}}$ $=0$ in all cases. $($ B $)$ Ratio of $\mathrm{I}_{\mathrm{Cl}, \mathrm{Vm}}$ recorded at $\mathrm{pH}_{\mathrm{i}} 4.0$ to $\mathrm{I}_{\mathrm{Cl}, \mathrm{Vm}}$ recorded at $\mathrm{pH}_{\mathrm{i}} 7.3$ utilized to determine the open probability at each Vm after intracellular acidification. Enhancement of open probability for WT channels (green line; $\mathrm{n}=10$ ) and $5 \mathrm{M}$ channels (orange line; $\mathrm{n}=13$ ) was induced by acidification to $\mathrm{pH}_{\mathrm{i}}=4.0$.

Despite this limitation and contrary to the result obtained at $\mathrm{pH}_{\mathrm{i}} 7.3$ (Fig. 3B), Vm activation of $\mathrm{I}_{\mathrm{Cl}, \mathrm{Vm}}$ at $\mathrm{pH}_{\mathrm{i}} 4.0$ was strongly weakened but not eliminated. Depolarizing to $+160 \mathrm{mV}$ induced a 1.4 -fold increase in $\mathrm{I}_{\mathrm{Cl}, \mathrm{Vm}}$ generated by $5 \mathrm{M}$ channels compared to $\mathrm{WT}_{\text {at }} \mathrm{pH}_{\mathrm{i}}$ 4.0. Thus, mutating $4 \mathrm{Glu}$ and 1 Asp located in the $\mathrm{Ca}^{2+}$-binding pocket of TMEM16A reduced but did not completely abolish the ability of intracellular $\mathrm{H}^{+}$to increase $\mathrm{I}_{\mathrm{Cl}, \mathrm{Vm}}$.

To investigate if the Vm dependence of $p K a$ was eliminated by mutating the acidic residues we performed concentration-response experiments in $5 \mathrm{M}$ channels. Figure $4 \mathrm{C}$ shows titration curves constructed using the $\mathrm{I}_{\mathrm{Cl}, \mathrm{Vm}}$ recorded between +60 to $+160 \mathrm{mV}$ from the whole cell (left) or inside-out patches (right). Unlike WT channels (Fig. 2B), the $5 \mathrm{M}$ mutant channels display nearly overlapping titration curves at different $\mathrm{Vm}$ indicating less $\mathrm{Vm}$ dependence. This behaviour was more evident for inside-out patch data possibly because we were able to test all $\left[\mathrm{H}^{+}\right]_{\mathrm{i}} \mathrm{s}$ in each patch. Curves were fit with the Hill equation to calculate $p K a$. Figure $4 \mathrm{D}$ (purple $=$ whole cell; green $=$ inside-out patches) shows $p K a$ values against $\mathrm{Vm}$. $p K a$ values fall in a range comprising 4.7 to 6 (note a smaller range for inside-out patch data), indicating that residues other than Glu and Asp are being protonated. These $p K a-\mathrm{Vm}$ curves were fitted with Eq. 2 to estimate $p K_{0}$ and $V m$ sensitivity. $p K_{0} / \delta$ values were $4.69 \pm 0.08 / 0.13 \pm 0.04$ (inside out) and 3.91 $\pm 0.14 / 0.70 \pm 0.07$ (whole cell). Thus, compared to WT (replotted in orange) protonation in $5 \mathrm{M}$ channels is less Vm-dependent. This loss of Vm dependence is also illustrated by the fact that this channel is partially open at a low $\left[\mathrm{H}^{+}\right]_{\mathrm{i}}$. Thus, mutating the acidic residues decreased the Vm dependence of TMEM16A titration lending support to the idea that the $\mathrm{Ca}^{2+}$-binding pocket is the target of intracellular $\mathrm{H}^{+}$. In addition, the activity of TMEM16A-5M channels was enhanced under acidic conditions by a weakly Vm-dependent protonation mechanism.

To further understand the mechanism by which intracellular $\mathrm{H}^{+}$activates TMEM16A, we investigated whether protonation of the $\mathrm{Ca}^{2+}$-binding pocket increases the open probability. To this end, we recorded $\mathrm{I}_{\mathrm{Cl}, \mathrm{Vm}}$ - Vm curves from inside-out patches consecutively exposed to $\mathrm{pH}_{\mathrm{i}} 7.3$ and 4.0. We used a ramp protocol that changed the $\mathrm{Vm}$ between -100 to $+200 \mathrm{mV}$ in $635 \mathrm{~ms}$. $\mathrm{pH}_{\mathrm{i}} 4.0$ was chosen because under this acidic condition $64 \%$ of the time the Glu side chain will be in the protonated state, assuming the $p K a$ value of Glu is 4.25 . Figure $5 \mathrm{~A}$ shows two sets of $\mathrm{I}_{\mathrm{Cl}, \mathrm{Vm}}-$ Vm curves recorded from patches excised from a cell expressing WT (left) or $5 \mathrm{M}$ (right) channels. At $\mathrm{pH}_{\mathrm{i}} 7.3$, the WT channels displayed a small $\mathrm{I}_{\mathrm{Cl}, \mathrm{Vm}}$ at all $\mathrm{Vm}$ range. However, upon exposure to a solution $\mathrm{pH}_{\mathrm{i}} 4.0$ the $\mathrm{I}_{\mathrm{Cl}, \mathrm{Vm}}$ was strongly enhanced resulting in an outward rectifying current. Similarly, in $5 \mathrm{M}$ channels (right) $\mathrm{I}_{\mathrm{Cl}, \mathrm{Vm}}$ increased further when the $\mathrm{pH}_{\mathrm{i}}$ went from 7.3 to 4.0 with little alteration in the reversal potentials $(\Delta \mathrm{Vr}=4.95 \pm 0.8$ for $\mathrm{WT}$ and $\Delta \mathrm{Vr}=4.9 \pm 0.9 \mathrm{mV}$ for $5 \mathrm{M})$. To determine whether the open probability was enhanced by acidification, we calculated the ratio of $\mathrm{I}_{\mathrm{Cl}, \mathrm{Vm}}$ at $\mathrm{pH}_{\mathrm{i}} 4.0$ and $7.3\left(\mathrm{I}_{\mathrm{pHi}=4} / \mathrm{I}_{\mathrm{pHi}=7.3}\right)$. This value is directly proportional to the changes in the open probability induced by the acidification at each $\mathrm{Vm}$. These ratios are shown in Fig. 5B. In WT channels the open probability (green) increased 3-fold at $0 \mathrm{mV}$ and 14 -fold at $200 \mathrm{mV}$, thus highlighting the effect of $\mathrm{Vm}$-dependent protonation on open probability. However, the ratio $\mathrm{I}_{\mathrm{pHi}=4} / \mathrm{I}_{\mathrm{pHi}=}$ ${ }_{7.3}$ for $5 \mathrm{M}$ channels was $\mathrm{Vm}$-independent (orange), albeit acidification produced a 3.5-fold increase in the open probability in the -100 to $+200 \mathrm{mV}$ range. Therefore, protonation is enough to grant $\mathrm{Vm}$-dependent activation to TMEM16A channels in the absence of intracellular $\mathrm{Ca}^{2+}$. Also, the titration data indicates that TMEM16A activity is enhanced by $\mathrm{Vm}$-independent protonation.

The data described show that the activation of TMEM16A in the absence of intracellular $\mathrm{Ca}^{2+}$ is enhanced by mutating the acidic residues of the $\mathrm{Ca}^{2+}$-binding pocket. We took advantage of the strong activation of $4 \mathrm{M}$ and $5 \mathrm{M}$ channels at $\mathrm{pH}_{\mathrm{i}} 7.3$ to record tail currents to analyse the effect of acidification on voltage-dependent activation. We recorded tail currents at $+100 \mathrm{mV}$ using a $\mathrm{P} / 8$ protocol in cells expressing $\mathrm{WT}, 4 \mathrm{M}$ and $5 \mathrm{M}$ channels dialyzed with 

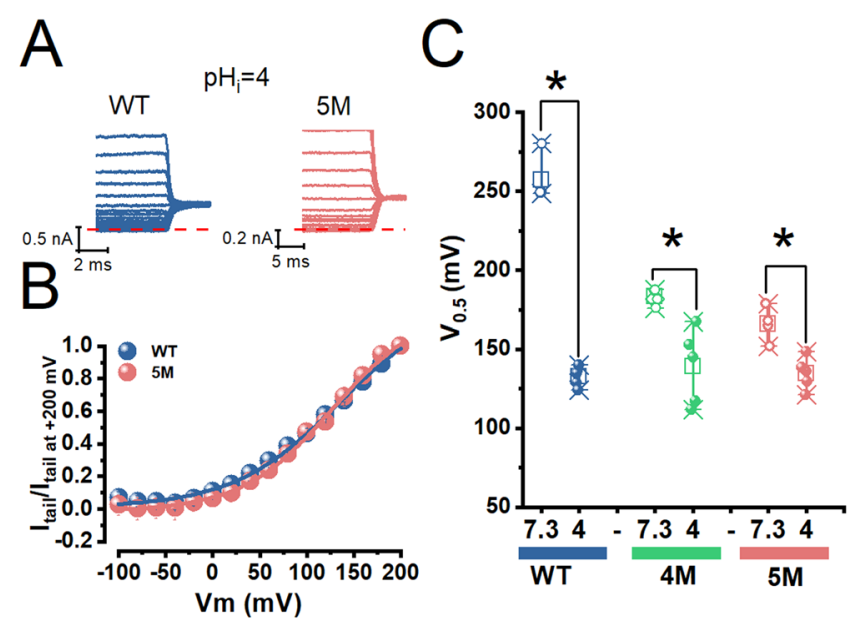

Figure 6. The acidic residues of the $\mathrm{Ca}^{2+}$-binding pocket control the voltage activation of TMEM16A. (A) Representative tail currents recorded at $+100 \mathrm{mV}$ from two cells expressing WT (blue) and $5 \mathrm{M}$ (pink) channels. For clarity, we only plot the last $10 \mathrm{~ms}$ of the currents generated by depolarizing pulses. Currents were recorded using a $\mathrm{P} / 8$ protocol from cells dialyzed with an internal solution with $\mathrm{pH}=4.0 .\left[\mathrm{Cl}^{-}\right]_{\mathrm{e}} /\left[\mathrm{Cl}^{-}\right]_{\mathrm{i}}=140 / 40 \mathrm{mM}$, $\mathrm{pH}_{\mathrm{e}}=7.3$ and $\left[\mathrm{Ca}^{2+}\right]_{\mathrm{i}}=0$ in all cases. (B) Corresponding activation curves constructed with the tail currents shown in A. Initial tail current magnitudes were measured and normalized to the value obtained at $+200 \mathrm{mV}$. Continuous lines are fits with the Boltzmann Equation. $\mathrm{V}_{0.5}=134.14 \pm 9.8 \mathrm{mV}$ and $\mathrm{z}=0.02$ for WT and $\mathrm{V}_{0.5}=$ $126.6 \pm 5.6 \mathrm{mV}$ and $\mathrm{z}=0.02$ for $5 \mathrm{M}$. (C) $\mathrm{V}_{0.5}$ values for WT (blue, $\mathrm{n}=4$ ), $4 \mathrm{M}$ (green, $\mathrm{n}=4$ ), and $5 \mathrm{M}$ (pink, $\mathrm{n}$ $=4$ ) channels determined at $\mathrm{pH}_{\mathrm{i}} 7.3$ (open symbols) and 4.0 (closed symbols $\mathrm{n}=5$ all cases). $\mathrm{V}_{0.5}$ values were determined as shown in $\mathrm{A}$ and $\mathrm{B} . \mathrm{V}_{0.5}$ values for $\mathrm{WT}$ at $\mathrm{pH}_{\mathrm{i}} 7.3(\mathrm{n}=4)$ were estimated by fitting the $\mathrm{I}_{\mathrm{Cl}, \mathrm{Vm}}-\mathrm{Vm}$ curves with Eq. 3. Statistical differences were showed with an asterisk, $\mathrm{p}=0.04$.

an internal solution $\mathrm{pH}_{\mathrm{i}}=4.0$. Because $\mathrm{I}_{\mathrm{Cl}, \mathrm{Vm}}$ reaches steady-state very fast, we employed $20 \mathrm{~ms}$ depolarization pulses (Fig. 6A). The Vm-dependent activation was measured by the $\mathrm{V}_{0.5}$ value (determined from Boltzmann equation fits to the normalized tail current vs Vm curves). $\mathrm{V}_{0.5}$ values were the same for WT, $5 \mathrm{M}$ and $4 \mathrm{M}$ channels (Fig. 6A-C); these values were in the range $129-140 \mathrm{mV}(\mathrm{WT}), 111-167 \mathrm{mV}(4 \mathrm{M})$, and $117-149 \mathrm{mV}(5 \mathrm{M})$. At $\mathrm{pH}_{\mathrm{i}} 7.3, \mathrm{~V}_{0.5}$ values were more positive for the three channels, indicating that acidification shifted the $\mathrm{Vm}$ dependence of activation. Although the $\mathrm{V}_{0.5}$ values for $4 \mathrm{M}$ and $5 \mathrm{M}$ channels were on average $17 \mathrm{mV}$ apart at $\mathrm{pH}_{\mathrm{i}} 7.3$, the statistical analysis indicated that at $\mathrm{p}<0.04$ the values were not different. However, this tendency and the effect of $\mathrm{pH}_{\mathrm{i}} 4.0$ on $4 \mathrm{M}$ channels suggest that protonating or mutating residue $\mathrm{E} 654$ facilitates voltage activation. The estimated $\mathrm{V}_{0.5}$ value for activation of WT channels at $\mathrm{pH}_{\mathrm{i}} 7.3$ was obtained by fitting the current-voltage relations with Eq. 3. The resulting values are plotted as open blue symbols in Fig. 6C. By comparing this result with that obtained at $\mathrm{pH}_{\mathrm{i}} 4.0$ (closed blue symbols) we can conclude that intracellular protons shifted the Vm activation by more than $-100 \mathrm{mV}$.

\section{Discussion}

TMEM16A gating in the absence of intracellular $\mathrm{Ca}^{2+}$ can be prompted by strong depolarizations, an elevation in temperature, mutating residues Ile637 and Gln645 in the sixth transmembrane segment (Ile641 and Gln649 in our clone) and deleting EAVK segment in the first intracellular loop ${ }^{23,36-38}$. To explain these results, an intrinsic Vm sensitivity in TMEM16A channels has been proposed ${ }^{37}$. However, in TMEM16A an obvious Vm-sensing domain is lacking. Since intracellular acidification reduces TMEM16A activity due to competition between $\mathrm{H}^{+}$ and $\mathrm{Ca}^{2+}$ for the $\mathrm{Ca}^{2+}$-binding pocket ${ }^{32,33}$, we hypothesized that TMEM16A could be gated by Vm-dependent protonation of Glu and Asp residues within the pocket. This is indeed what we found. Our data do not rule out the presence of voltage-sensing domains, instead reveals an unexpected source of Vm dependence, namely Vm dependent protonation. As we acidified the cytosolic side of TMEM16A a large outward $\mathrm{I}_{\mathrm{Cl}, \mathrm{Vm}}$ that lacked time dependence was activated by depolarizations in the absence of intracellular $\mathrm{Ca}^{2+}$. The equilibrium constant of protonation and the apparent open probability both increased in a Vm-dependent manner. These effects were reduced after mutating Glu and Asp residues from the $\mathrm{Ca}^{2+}$-binding pocket, confirming that $\mathrm{H}^{+}$titrate these residues. Nevertheless, in TMEM16A-5M a channel with all the residues mutated, intracellular acidification enhanced channel activity although the effect was Vm-independent. The estimated $p K a$ of this secondary activation is between 4.5 and 6 suggesting protonation of His and probably Asp residues located in the cytosolic side. Together, our data is consistent with a mechanism depicted by the Scheme in Fig. 7.

We propose that intracellular $\mathrm{H}^{+}$ions interact in a Vm-independent manner $\left(K_{1}=\beta_{1} / \alpha_{1}\right)$ with acidic residues (shown in red) located in the cytosolic side of TMEM16A (shown in blue light embedded in a grey membrane; modified from $5 \mathrm{OYB}^{25}$ ) outside the electrical field. A depolarizing stimulus will push $\mathrm{H}^{+}$into the electrical field where they can interact with the acidic residues of the $\mathrm{Ca}^{2+}$-binding pocket $\left(K_{2}=\beta_{2} / \alpha_{2}\right)$. Once these residues are protonated (shown in navy), the channels reach the conductive state through a Vm dependent transition $\left(K_{3}=\beta_{3} /\right.$ $\alpha_{3}$ ) and generate $\mathrm{I}_{\mathrm{Cl}, \mathrm{Vm}}$.

The effects of intracellular $\mathrm{H}^{+}$observed on TMEM16A are comparable to those reported on human SLO1 BK potassium channel ${ }^{39}$. Both channels are activated in the absence of intracellular $\mathrm{Ca}^{2+}$ by intracellular acidification 


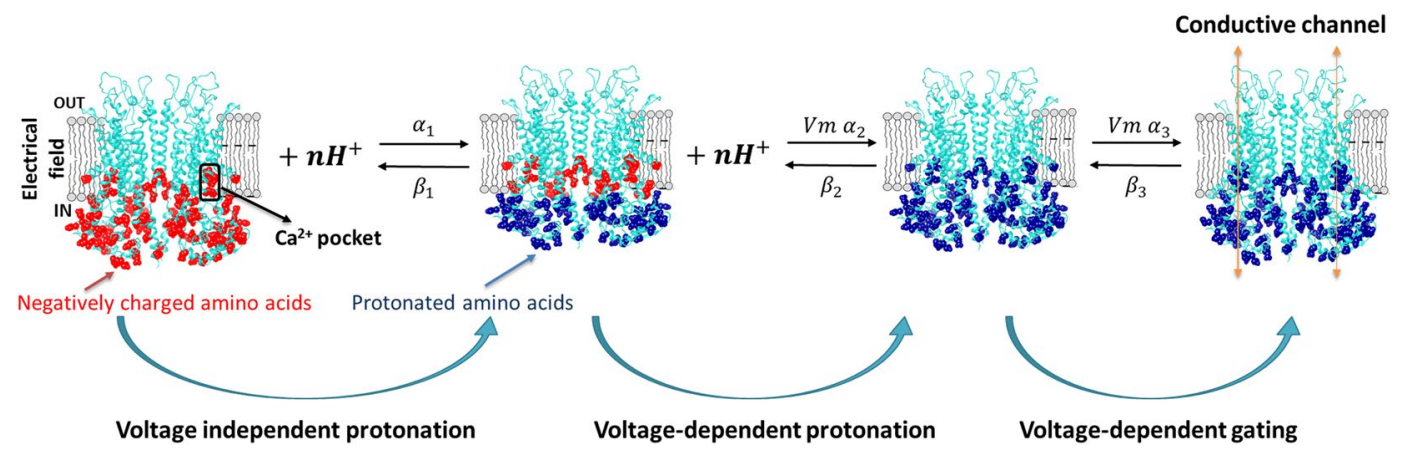

Figure 7. Schematic representation of the proposed mechanism of TMEM16A activation by voltageindependent and voltage-dependent protonation. We advocate that voltage activation of TMEM16A in the absence of intracellular $\mathrm{Ca}^{2+}$ by protonation proceeds in three steps. The first and second are voltageindependent and voltage-dependent protonation steps, respectively. Channel opening is achieved by a voltagedependent transition occurring during the last step. $\alpha_{1}, \alpha_{2}$, and $\alpha_{3}$ are forward rate constants whereas $\beta_{1}, \beta_{2}$ and $\beta_{3}$ are backward rate constants. TMEM16A is depicted in blue embedded in a grey membrane. Red dots are intracellular un-protonated acidic residues that are potential targets of intracellular protons. Residues outside the electrical field are protonated in a voltage-independent manner (navy). Inside the black rectangle are the acidic residues of the $\mathrm{Ca}^{2+}$ pocket (one subunit) that are protonated in a voltage-dependent manner.

and the targets are $\mathrm{Ca}^{2+}$ sensing residues. Interestingly, intracellular $\mathrm{H}^{+}$target two His residues, as well as one Asp residue located within the RCK1 domain of BK channels; mutating the His residues, abolished the activating effect of $\mathrm{H}^{+}$. In agreement with this, the equilibrium constant of $\mathrm{BK}$ protonation has a value of about 6.5 at $+100 \mathrm{mV}$ and displays shallow Vm dependence ${ }^{39}$. Here intracellular $\mathrm{H}^{+}$activates TMEM16A by Vm-dependent and independent mechanisms. The Vm-independent $p K a$ has a value of about 5.0 at $+100 \mathrm{mV}$, which may suggest titration of Glu, Cys or His residues ${ }^{40}$ just like in BK channels.

Full activation of TMEM16A by intracellular $\mathrm{Ca}^{2+}$ is achieved by neutralization of the electrostatic potential generated by the acidic residues of the $\mathrm{Ca}^{2+}$-binding pocket and the subsequent movement of TM 6 towards $\mathrm{TM}^{30}$. This process seems to be assisted by phosphatidylinositol 4,5 bisphosphate ${ }^{41-43}$. Neutralization of the electrostatic potential by $\mathrm{Ca}^{2+}$ is illustrated in TMEM16A Gly644Pro mutant channels where intracellular $\mathrm{Ca}^{2+}$ can abolish the strong outward rectification displayed by these channels ${ }^{30}$. In the "constitutively protonated" TMEM16A 5 M channel the electrostatic potential has been neutralized, however, the channel was still activated by $\mathrm{Vm}$ and showed outward rectification. This implies that neutralizing the electrostatic potential is not sufficient to abolish rectification. This idea is supported by the strong outward rectification observed under intracellular acidic conditions, which should partially or abolish the electrostatic potential. Alternatively, TM6 may remain bound to TM4 in TMEM16A $5 \mathrm{M}$ thus inducing rectification.

The present work together with a previous report from our group ${ }^{44}$ shows that TMEM16A is the target of extraand intracellular $\mathrm{H}^{+}$. In both cases, protonation of acidic residues enhanced the open probability of the channel albeit extracellular $\mathrm{H}^{+}$do so independently of $\mathrm{Vm}_{\text {and }} \mathrm{Ca}^{2+}$. What would be the physiological consequences of TMEM16A regulation by protons? Although we cannot answer this question yet, we envision that this regulatory process would be important to both TMEM16 channels and scramblases since the residues targeted by $\mathrm{H}^{+}$are present in these proteins. Cancer cells overexpress TMEM16A channels and experience a large $\mathrm{pH}$ gradient ${ }^{20,21,45,46}$, conditions that facilitate cell migration and cancer progression. In these cells, the extracellular side is acidic whereas the cytosol is alkaline, and this favours TMEM16A activity. A key salient property of this regulation is that increasing the $\left[\mathrm{H}^{+}\right]_{\mathrm{e}}$ or the $\left[\mathrm{H}^{+}\right]_{\mathrm{i}}$ increases the current size without changing the fast kinetics. The activation of TMEM16A by $\mathrm{Vm}$ in the absence of intracellular $\mathrm{Ca}^{2+}$ occurred in less than $1.0 \mathrm{~ms}$, well within the time scale of the electrical activity of excitable cells. Rapid activation of TMEM16A can regulate the electrical activity by inducing membrane depolarization or by accelerating action potential repolarization; this has been shown in neurons from dorsal root ganglia, cholinergic neurons of the medial habenula and muscle cells ${ }^{36,47}$. Thus, activation of TMEM16A enables neurons to respond to thermal stimulus, control anxiety-related behaviour ${ }^{36,47}$ and increase the frequency of action potentials in skeletal muscle cells of zebrafish ${ }^{48}$. A more direct physiological role for TMEM16A regulation by protons is suggested by its simultaneous activation with $\mathrm{H}^{+}$ATPase in the apical membrane of proximal tubules of mouse kidney ${ }^{49}$. In this scenario, a parallel $\mathrm{Cl}^{-}$flux via TMEM16A would serve as a counter ion for $\mathrm{H}^{+}$transport by the V-ATPase. Also, it is interesting to notice that the dimeric channels TMEM16A and CLC-0 are both activated by intracellular to protons ${ }^{50}$. In conclusion, we propose that intracellular $\mathrm{H}^{+}$endow TMEM16A with Vm gating in the absence of intracellular $\mathrm{Ca}^{2+}$ by a mechanism that includes $\mathrm{Vm}$-independent titration of cytosolic residues and $\mathrm{Vm}$-dependent titration of acidic residues located in the $\mathrm{Ca}^{2+}$-binding pocket.

\section{Methods}

Cell culture and protein expression. Human embryonic kidney 293 cells (HEK-293) were cultured in Dulbecco's modified Eagle medium (DMEM, GIBCO BRL) supplemented with 10\% FBS and 0.1\% penicillin-streptomycin at $37 \mathrm{C}^{\circ}$ in a $95 \% \mathrm{O}_{2} / 5 \% \mathrm{CO}_{2}$ atmosphere. Wild type mouse TMEM16A (ac) and mutant DNAs were cloned into pIRES2-EGFP (Clontech, Mountain View, CA, USA) or pEGFP-N1 vectors. Mutations were introduced using the Quick-change kit (Aligent) and verified by sequencing. HEK-293 cells were transfected with 
$1 \mu \mathrm{g} / \mu \mathrm{l}$ cDNA using Polyfect transfection reagent (QIAGEN), according to the manufacturer's instructions. Cells were used $12 \mathrm{~h}$ after transfection. For whole cell recordings, we seeded cells at low density whereas for inside-out recordings stably transfected cells with TMEM16A or transiently transfected mutants were plated onto poly-1lysine coated coverslips.

Chloride current recordings by patch clamp. Vm-activated macroscopic chloride $\left(\mathrm{Cl}^{-}\right)$currents $\left(\mathrm{I}_{\mathrm{Cl}, \mathrm{Vm}}\right)$ were recorded at room temperature $\left(21-23^{\circ} \mathrm{C}\right)$ from whole cells or inside-out patches expressing wild type (WT) or mutant TMEM16A channels using the patch clamp technique as we previously reported ${ }^{44,51}$. We selected EGFP fluorescent HEK-293 cells using an inverted microscope equipped with UV illumination. Borosilicate patch pipettes were fabricated using P-97 electrode puller (Sutter Instruments CO.). The electrode resistance was 3-5 $\mathrm{M} \Omega$ for whole cell or 1-2 M $\Omega$ for inside-out patches. The stimulation protocol consisted of Vm steps from -100 to $+160 \mathrm{mV}$ delivered every $7 \mathrm{~s}$ from a holding potential of $-30 \mathrm{mV}$, followed by a repolarization potential to -100 or $+100 \mathrm{mV}$. $\mathrm{I}_{\mathrm{Cl}, \mathrm{Vm}}$ from inside-out patches were recorded using a $635 \mathrm{~ms} \mathrm{Vm} \mathrm{ramp}(-100$ and $+200 \mathrm{mV})$. Data were acquired using an Axopatch $200 \mathrm{~B}$ amplifier and the pClamp10 software (Molecular Devices). $\mathrm{I}_{\mathrm{Cl}, \mathrm{Vm}}$ was filtered at $5 \mathrm{kHz}$ and digitized at $10 \mathrm{kHz}$ while the bath was grounded using $3 \mathrm{M} \mathrm{KCl}$ agar-bridge connected to an $\mathrm{Ag} / \mathrm{AgCl}$ reference electrode. Solutions were applied using a home-made gravity perfusion system.

Solutions to record chloride currents. The extracellular solution contained (in mM): 139 TEA-Cl, 20 HEPES, $0.5 \mathrm{CaCl}_{2}$, and $110 \mathrm{D}$-mannitol. We adjusted the $\mathrm{pH}$ to 7.3 with TEAOH or $\mathrm{NaOH}$. The external solutions were made hypertonic (380-400 $\mathrm{mOsm} / \mathrm{kg}$ measured by the vapour pressure point method with a VAPRO, Wescor Inc., South Logan, UT, USA) by adding D-mannitol to preclude activation of endogenous volume-sensitive $\mathrm{Cl}^{-}$currents ${ }^{52}$. To determine the anion selectivity sequence, we replaced $100 \% \mathrm{Cl}^{-}$with the desired anion. We constructed concentration-response curves for the blockade of $\mathrm{I}_{\mathrm{Cl}, \mathrm{Vm}}$ by tannic and anthracene-9-carboxylic acids by perifusing standard external solution containing increasing concentrations of the inhibitors. To avoid precipitation of tannic acid, we used an extracellular solution containing $139 \mathrm{mM} \mathrm{NaCl}$ instead of $139 \mathrm{mM}$ TEA-Cl.

The standard intracellular solution with $\left[\mathrm{Ca}^{2+}\right]=0$ and $\mathrm{pH}=7.3$ contained (in $\mathrm{mM}$ ): 40 TEA-Cl, 50 HEPES, EGTA-TEA 25.24 and $85 \mathrm{D}$-mannitol. To obtain $\left[\mathrm{Ca}^{2+}\right]=0.2 \mu \mathrm{M}$, we added $5.24 \mathrm{mM} \mathrm{CaCl}_{2}$ to the standard intracellular solution and TEA-Cl was reduced to $30 \mathrm{mM}$. To test the effect of intracellular $\left[\mathrm{H}^{+}\right]_{\mathrm{i}}$ on $\mathrm{I}_{\mathrm{Cl}, \mathrm{Vm}}$, the $\mathrm{pH}$ of the standard solution was adjusted to 4.0 with $50 \mathrm{mM}$ tartaric acid; to $4.0,5.0$, and 6.0 with $50 \mathrm{mM}$ MES; to 7.3 with $50 \mathrm{mM}$ HEPES; to 8.0 and 9.0 with $50 \mathrm{mM}$ bicine. The $\mathrm{pH}$ was adjusted with TEA-OH, the tonicity was 290-300 $\mathrm{mosm} / \mathrm{kg}$ and the free $\left[\mathrm{Ca}^{2+}\right]$ was calculated using the MAXCHELATOR program (maxchelator.stanford.edu).

All chemicals were purchased from Sigma-Aldrich Co. St. Louis, MO, USA

Data analysis. Data were analysed and plotted using pClamp 10 (Molecular Devices) and Origin 9 (Origin Lab, Northampton, MA, USA). Red dotted lines in Figures indicate zero current. $\mathrm{I}_{\mathrm{Cl}, \mathrm{Vm}}$ values at each Vm were measured at the end of each depolarization and then corrected for cell size using the cell capacitance. Alternatively, $\mathrm{I}_{\mathrm{Cl}, \mathrm{Vm}}$ values were normalized against the current measured at $+160 \mathrm{mV}$. Normalized $\mathrm{I}_{\mathrm{Cl}, \mathrm{Vm}}$ values were then averaged.

The effect of different blocker concentrations ([B]) or $\left[\mathrm{H}^{+}\right]_{\mathrm{i}}$ on $\mathrm{I}_{\mathrm{Cl}, \mathrm{Vm}}$ was quantified from concentration-response curves using the Hill Eq. 1 assuming that $N$ is the number of $\mathrm{H}^{+}$or $\mathrm{B}$ interacting with one channel according to the following Scheme I:

$$
\begin{gathered}
C+N B \underset{\beta}{\stackrel{\alpha}{\rightleftharpoons}} C B_{N} \text { or } C+N H^{+} \underset{k_{-1}}{\rightleftharpoons} C H_{N} \\
\text { Response }=\left(I_{\text {max }}-I_{\text {min }}\right) \frac{1}{1+\left(\frac{I C_{50}}{[B]}\right)^{N}}+I_{\text {min }}
\end{gathered}
$$

where $\mathrm{I}_{\max }$ and $\mathrm{I}_{\min }$ are the maximum and minimum response, $\mathrm{IC}_{50}$ is the concentration of inhibitor ([B]) needed to obtain half $\mathrm{I}_{\max }-\mathrm{I}_{\min }$ inhibition; it also represents the equilibrium constant of protonation $K$, and $\mathrm{N}$ is the Hill coefficient. For the Vm dependence of $\mathrm{K}$, we fitted titration curves at different $\mathrm{Vm}$, the corresponding $\mathrm{K}$ was converted to $\mathrm{pK}(-\log \mathrm{K})$ and plotted against Vm. The curve was fit with Eq. $2^{53-55}$ :

$$
p K(V m)=p K_{0}+\frac{z \delta F V m}{2.303 R T}
$$

where $p K_{0}$ is the effective $\mathrm{pH}_{\mathrm{i}}$ needed to obtain half-activation when $\mathrm{Vm}=0 \mathrm{mV}, \mathrm{R}$ is the gas constant, $\mathrm{T}$ is absolute temperature, $\mathrm{F}$ is Faraday's constant, $\mathrm{z}$ is the charge, $\delta$ is the electrical distance from the inside. To obtain the $\mathrm{V}_{0.5}$ value of TMEM16A-WT, the current-voltage curve was adjusted to the following equation:

$$
y=\frac{(V m-V r) * G_{\max }}{1+e^{\left(V m-V_{0.5}\right) / d x}}
$$

where $\mathrm{Vm}$ is the clamping voltage, $\mathrm{Vr}$ is the reversal potential, $\mathrm{V}_{0.5}$ is the voltage at which the $50 \%$ of channels were activated, $\mathrm{G}_{\max }$ is the estimated maximum conductance and $d x$ is the Vm sensitivity. We estimate the liquid junction potentials using the Clampex routine of pClamp and used them to correct the reversal potential values. 
Pooled data are presented as mean \pm S.E.M. of $n$ (number of independent experiments). Statistically significant differences between means were determined using a Student $t$-test or ANOVA.

Received: 19 February 2020; Accepted: 21 March 2020;

Published online: 20 April 2020

\section{References}

1. Schroeder, B. C., Cheng, T., Jan, Y. N. \& Jan, L. Y. Expression Cloning of TMEM16A as a Calcium-Activated Chloride Channel Subunit. Cell 134, 1019-1029 (2008).

2. Caputo, A. et al. TMEM16A, a membrane protein associated with calcium-dependent chloride channel activity. Science (80-). 322, 590-594 (2008)

3. Yang, Y. D. et al. TMEM16A confers receptor-activated calcium-dependent chloride conductance. Nat. ... 455, 1210-1215 (2008).

4. Hartzell, C., Putzier, I. \& Arreola, J. Calcium-activated chloride channels. Annual Review of Physiology vol. 67 (2005).

5. Pedemonte, N. \& Galietta, L. J. V. Structure and function of TMEM16 proteins (anoctamins). Physiol. Rev. 94, 419-59 (2014).

6. Pusch, M., Ludewig, U. \& Jentsch, T. J. Temperature dependence of fast and slow gating relaxations of ClC-0 chloride channels. J. Gen. Physiol. 109, 105-116 (1997).

7. Hartzell, C., Putzier, I. \& Arreola, J. Calcium-Activated Chloride Channels. Annu. Rev. Physiol. 67, 719-758 (2005).

8. Duan, D. Phenomics of cardiac chloride channels: the systematic study of chloride channel function in the heart. J. Physiol. 587, 2163-2177 (2009).

9. Romanenko, V. G. et al. Tmem16A encodes the Ca2+-activated $\mathrm{Cl}$ - channel in mouse submandibular salivary gland acinar cells. J. Biol. Chem. 285, 12990-13001 (2010).

10. Hwang, S. J. et al. Expression of anoctamin 1/TMEM16A by interstitial cells of Cajal is fundamental for slow wave activity in gastrointestinal muscles. J Physiol 587, 4887-904 (2009).

11. Heinze, C. et al. Disruption of vascular Ca $2+$-activated chloride currents lowers blood pressure. J. Clin. Invest. 124, 675-86 (2014).

12. Crutzen, R. et al. Anoctamin 1 (Ano1) is required for glucose-induced membrane potential oscillations and insulin secretion by murine $\beta$-cells. Pflügers Arch. Eur. J. Physiol. 468, 573-91 (2016).

13. Huang, F. et al. Calcium-activated chloride channel TMEM16A modulates mucin secretion and airway smooth muscle contraction. Proc. Natl. Acad. Sci. USA 109, 16354-9 (2012).

14. Pietra, G., Dibattista, M., Menini, A., Reisert, J. \& Boccaccio, A. The Ca2+-activated Cl-channel TMEM16B regulates action potential firing and axonal targeting in olfactory sensory neurons. J. Gen. Physiol., https://doi.org/10.1085/jgp.201611622 (2016).

15. Wozniak, K. L., Phelps, W. A., Tembo, M., Lee, M. T. \& Carlson, A. E. The TMEM16A channel mediates the fast polyspermy block in Xenopus laevis. J. Gen. Physiol. https://doi.org/10.1085/jgp.201812071 (2018).

16. Cordero-Martínez, J. et al. TMEM16A inhibition impedes capacitation and acquisition of hyperactivated motility in guinea pig sperm. J. Cell. Biochem. 119, 5944-5959 (2018).

17. He, M. et al. Cytoplasmic Cl-couples membrane remodeling to epithelial morphogenesis. Proc. Natl. Acad. Sci. USA 114, E11161-E11169 (2017)

18. Duvvuri, U. et al. TMEM16A induces MAPK and contributes directly to tumorigenesis and cancer progression. Cancer Res. 72, 3270-3281 (2012).

19. Qu, Z. et al. The $\mathrm{Ca}(2+)$-activated $\mathrm{Cl}(-)$ channel, ANO1 (TMEM16A), is a double-edged sword in cell proliferation and tumorigenesis. Cancer medicine vol. 3, 453-461 (2014).

20. Crottès, D. \& Jan, L. Y. The multifaceted role of TMEM16A in cancer. Cell Calcium, https://doi.org/10.1016/j.ceca.2019.06.004 (2019).

21. Britschgi, A. et al. Calcium-activated chloride channel ANO1 promotes breast cancer progression by activating EGFR and CAMK signaling. Proc. Natl. Acad. Sci. USA, https://doi.org/10.1073/pnas.1217072110 (2013).

22. Arreola, J., Melvin, J. E. \& Begenisich, T. Activation of calcium-dependent chloride channels in rat parotid acinar cells. J. Gen. Physiol. 108, 35-47 (1996).

23. Xiao, Q. et al. Voltage- and calcium-dependent gating of TMEM16A/Anol chloride channels are physically coupled by the first intracellular loop. Proc. Natl. Acad. Sci. USA 108, 8891-8896 (2011).

24. Tien, J. et al. A comprehensive search for calcium binding sites critical for TMEM16A calcium-activated chloride channel activity: (A) Two competing models to explain TMEM16A calcium sensitivity have been proposed. It is unclear whether calcium directly binds to TMEM16A-. Elife 3, 1-19 (2014).

25. Paulino, C., Kalienkova, V., Lam, A. K. M., Neldner, Y. \& Dutzler, R. Activation mechanism of the calcium-activated chloride channel TMEM16A revealed by cryo-EM. Nature 552, 421-425 (2017).

26. Yu, K., Duran, C., Qu, Z., Cui, Y. Y. \& Hartzell, H. C. Explaining calcium-dependent gating of anoctamin-1 chloride channels requires a revised topology. Circ. Res. 110, 990-999 (2012).

27. Tien, J. et al. A comprehensive search for calcium binding sites critical for TMEM16A calcium-activated chloride channel activity. Elife 3, 1-19 (2014).

28. Parker, I. \& Miledi, R. Changes in intracellular calcium and in membrane currents evoked by injection of inositol trisphosphate into Xenopus oocytes. Proc. R. Soc. London - Biol. Sci. 228, 307-315 (1986).

29. Ni, Y. L., Kuan, A. S. \& Chen, T. Y. Activation and inhibition of TMEM16A calcium-activated chloride channels. PLoS One 9, 4-6 (2014).

30. Lam, A. K. M. \& Dutzler, R. Calcium-dependent electrostatic control of anion access to the pore of the calcium-activated chloride channel TMEM16A. Elife 7 (2018).

31. Romani, A. M. P. Intracellular magnesium homeostasis. Magnesium in the Central Nervous System (2011).

32. Chun, H. et al. Protons inhibit anoctamin 1 by competing with calcium. Cell Calcium 58, 431-441 (2015).

33. Arreola, J., Melvin, J. E. \& Begenisich, T. Inhibition of $\mathrm{Ca} 2+$-dependent $\mathrm{Cl}-$ channels from secretory epithelial cells by low internal pH. J. Membr. Biol., https://doi.org/10.1007/BF00235400 (1995).

34. Namkung, W., Thiagarajah, J. R., Phuan, P. W. \& Verkman, A. S. Inhibition of Ca2+-activated $\mathrm{Cl}-$ channels by gallotannins as a possible molecular basis for health benefits of red wine and green tea. FASEB J. 24, 4178-4186 (2010).

35. Ta, C. M., Adomaviciene, A., Rorsman, N. J. G., Garnett, H. \& Tammaro, P. Mechanism of allosteric activation of TMEM16A/ANO1 channels by a commonly used chloride channel blocker. Br. J. Pharmacol. 173, 511-528 (2016).

36. Cho, H. et al. The calcium-activated chloride channel anoctamin 1 acts as a heat sensor in nociceptive neurons. Nat. Neurosci. 15 , 1015-1021 (2012).

37. Peters, C. J. et al. The Sixth Transmembrane Segment is a Major Gating Component of the TMEM16A Calcium-Activated Chloride Channel. Neuron 97, 1063-1077.e4 (2018).

38. Cruz-Rangel, S. et al. Gating modes of calcium-activated chloride channels TMEM16A and TMEM16B. J. Physiol. 593 (2015).

39. Avdonin, V., Tang, X. D. \& Hoshi, T. Stimulatory action of internal protons on Slo1 BK channels. Biophys. J. 84, 2969-2980 (2003).

40. Pahari, S., Sun, L. \& Alexov, E. PKAD: a database of experimentally measured pKa values of ionizable groups in proteins. Database (Oxford). 2019 (2019) 
41. Tembo, M., Wozniak, K. L., Bainbridge, R. E. \& Carlson, A. E. Phosphatidylinositol 4,5-bisphosphate (PIP2) and Ca2 are both required to open the Cl channel TMEM16A. J. Biol. Chem. 294, 12556-12564 (2019).

42. De Jesús-Pérez, J. J. et al. Phosphatidylinositol 4,5-bisphosphate, cholesterol, and fatty acids modulate the calcium-activated chloride channel TMEM16A (ANO1). Biochim. Biophys. Acta - Mol. Cell Biol. Lipids 1863, 299-312 (2018).

43. Arreola, J. \& Hartzell, H. C. Wasted TMEM16A channels are rescued by phosphatidylinositol 4,5-bisphosphate. Cell Calcium 84 (2019).

44. Cruz-Rangel, S. et al. Extracellular protons enable activation of the calcium-dependent chloride channel TMEM16A. J. Physiol. 595, 1515-1531 (2017).

45. Chiche, J., Brahimi-Horn, M. C. \& Pouysségur, J. Tumour hypoxia induces a metabolic shift causing acidosis: A common feature in cancer. J. Cell. Mol. Med., https://doi.org/10.1111/j.1582-4934.2009.00994.x (2010).

46. Persi, E. et al. Systems analysis of intracellular $\mathrm{pH}$ vulnerabilities for cancer therapy. Nat. Commun. 9 (2018)

47. Cho, C. et al. TMEM16A expression in cholinergic neurons of the medial habenula mediates anxiety-related behaviors. EMBO Rep., https://doi.org/10.15252/embr.201948097 (2019).

48. Dayal, A., Ng, S. F. J. \& Grabner, M. Ca $2+$-activated Cl- channel TMEM16A/ANO1 identified in zebrafish skeletal muscle is crucial for action potential acceleration. Nat. Commun. 10 (2019).

49. Faria, D. et al. The calcium-activated chloride channel Anoctamin 1 contributes to the regulation of renal function. Kidney Int. 85, 1369-1381 (2014).

50. Traverso, S., Zifarelli, G., Aiello, R. \& Pusch, M. Proton sensing of CLC-0 mutant E166D. J. Gen. Physiol. 127, 51-65 (2006).

51. Cruz-Rangel, S. et al. Gating modes of calcium-activated chloride channels TMEM16A and TMEM16B. J. Physiol. 593, 5283-5298 (2015).

52. Hernández-Carballo, C. Y., De Santiago-Castillo, J. A., Rosales-Saavedra, T., Pérez-Cornejo, P. \& Arreola, J. Control of volumesensitive chloride channel inactivation by the coupled action of intracellular chloride and extracellular protons. Pflugers Arch. Eur. J. Physiol. 460, 633-644 (2010).

53. Woodhull, A. M. Ionic Blockage of Sodium Channels in Nerve. J. Gen. Physiol. 61, 687-708 (1973).

54. Hille, B. The selective inhibition of delayed potassium currents in nerve by tetraethylammonium ion. J. Gen. Physiol. 50, 1287-1302 (1967).

55. Hille, B. Ion Channels of Excitable Membranes. (Sinauer Associates Is an Imprint of Oxford University Press, 2001).

\section{Acknowledgements}

We thank C.Y. Hernandez-Carballo for excellent technical assistance and Drs A. Rodriguez-Menchaca and Ataulfo Martinez-Torres for their constructive comments. This study was supported in part by grants: CB-219949 and FC-2016 1955 from CONACyT, Mexico to JA, PPC and IAF. GSC is the recipient of a Graduate Student Fellowship 297721 from CONACYT Mexico.

\section{Author contributions}

G.S.C. Conception, design, performed and analysed whole-cell experiments. I.A.F. Design, performed inside out patches experiments and analysed the data. J.J. and De.J.P. Conception of the project and wrote the manuscript. A.S.S. Design and performed whole-cell experiments. P.P.C. Conception, design experiments, wrote the manuscript, and secure funds for the project. J.A. Conception, design the project and experiments, analysed data, wrote the manuscript and secure funds for the project. All authors approved the submitted version of the work and agreed to be personally accountable for the authors own contributions and to ensure that questions related to the accuracy or integrity of any part of the work, even ones in which the author was not personally involved, are appropriately investigated, resolved, and the resolution documented in the literature.

\section{Competing interests}

The authors declare no competing interests.

\section{Additional information}

Supplementary information is available for this paper at https://doi.org/10.1038/s41598-020-62860-9.

Correspondence and requests for materials should be addressed to J.A.

Reprints and permissions information is available at www.nature.com/reprints.

Publisher's note Springer Nature remains neutral with regard to jurisdictional claims in published maps and institutional affiliations.

Open Access This article is licensed under a Creative Commons Attribution 4.0 International License, which permits use, sharing, adaptation, distribution and reproduction in any medium or format, as long as you give appropriate credit to the original author(s) and the source, provide a link to the Creative Commons license, and indicate if changes were made. The images or other third party material in this article are included in the article's Creative Commons license, unless indicated otherwise in a credit line to the material. If material is not included in the article's Creative Commons license and your intended use is not permitted by statutory regulation or exceeds the permitted use, you will need to obtain permission directly from the copyright holder. To view a copy of this license, visit http://creativecommons.org/licenses/by/4.0/.

(C) The Author(s) 2020 